\title{
Duygusal Emek Davranışı ve Tükenmişlik Arasındaki İlişki: Örgütsel Özdeşleşmenin Aracilık Etkisi (The Relationship Between Emotional Labor Behavior and Burnout: The Mediating Effect of Organizational Identification)
}

\section{Seval AKSOY KÜRÜ iD a}

a Gebze Teknik Üniversitesi, Sosyal Bilimler Enstitüsü, İşletme Anabilim Dalı, Kocaeli, Türkiye. drsevalaksoykuru@gmail.com

\begin{tabular}{ll}
\hline MAKALE BILGISI & ÖZET \\
\hline Anahtar Kelimeler: & Amaç-Bu çalışmada sağlık personellerinin duygusal emek davranışı ve tükenmişliği arasındaki ilişki \\
Duygusal emek & ve bu ilişkide örgütsel özdeşleşmenin aracılık etkisinin tespit edilmesi amaçlanmaktadır. \\
Tükenmişlik & Yöntem - Araştırmada ilişkisel tarama modeli kullanılmıştır. Araştırmanın örneklemini, İstanbul İl \\
Örgütsel özdeşleşme & Sağlık Müdürlügü Sağlı Araştırmaları Şube Müdürlügü Özel Yataklı Sağlık Hizmetleri Şube \\
Aracıllk testi & Müdürlüğüne bağlı özel yataklı hastanelerde çalışan 784 sağlık personelleri oluşturmaktadır. \\
Sağlık personelleri & Betimleyici istatistikler, korelasyon analiz(leri), geçerlilik ve güvenirlik testleri ve keşfedici faktör \\
& analizleri için SPSS paket programı kullanılmıştır. Doğrulayıcı faktör analizleri, path analizleri ve \\
& aracılık etkisi analizleri için de YEM (AMOS) paket programı kullanılmıştır.
\end{tabular}

Gönderilme Tarihi 30 Nisan 2020

Revizyon Tarihi 15 Ocak 2021 Kabul Tarihi 5 Mart 2021

Makale Kategorisi: Araştırma Makalesi

Bulgular - Yapısal eşitlik modellemesi sonuçlarına göre; duygusal emeğin yüzeysel davranış, derinden davranış ve doğal davranış boyutlarının tükenmişliğin kişisel başarı hissinde azalma, duygusal tükenme ve duyarsızlaşmaya etkisi olduğu görülmektedir. Örgütsel özdeşleşme üzerinde ise duygusal emeğin derinden davranış ve doğal davranış boyutlarının etkisinin olduğu görülmektedir. Örgütsel özdeşleşmenin de tükenmişliğin kişisel başarı hissinde azalma, duyarsızlaşma ve duygusal tükenme üzerinde etkisi olduğu görülmektedir. Yüzeysel davranışın örgütsel özdeşleşme üzerinde etkisi bulgulanmadığı için, yüzeysel davranışın tükenmişliğin kişisel başarı hissinde azalma, duygusal tükenme ve duyarsızlaşmaya etkisinde örgütsel özdeşleşmenin aracılık etkisi test edilememiştir. Derinden davranışın tükenmişliğin kişisel başarı hissinde azalma, duygusal tükenme ve duyarsızlaşmaya etkisinde örgütsel özdeşleşme, tam aracılık rolü oynamaktadır. Doğal davranışın tükenmişliğin kişisel başarı hissinde azalma ve duyarsızlaşmaya etkisinde örgütsel özdeşleşme kısmi aracılık rolü oynarken ve duygusal tükenmeye etkisinde ise tam aracılık rolü oynamaktadır.

Tartışma - Sağlık sektöründeki işin ve çalışanların, önem ve değerinin dikkate alınması gerekmektedir. Çünkü, sağlık personelleri sadece fiziksel ve zihinsel emekle çalışmamaktadır. Bunlara ek olarak duygularını da bir emek unsuru olarak sürece dahil etmektedirler. Örgütler için örgütüyle özdeşleşme yaşayan çalışanlar değerlidir. Bu nedenle de her bir sağlık personelinin duygularına ve duygularının davranışa dönüşme sürecine yönetim tarafından mümkün olduğunca özen gösterilmelidir. Sağlık personellerinin örgütüyle bir bütün olması için yönetimin onlara yönelik anlayış ve desteğini açıkça ortaya koyması gerekir. Böylece, çalışma ortamında karşılaşılan çeşitli olaylara ve durumlara karşı sağlık personel(ler)inin tepkileri doğrudan gözlemlenebilir. Sağlık personellerinin tükenmişlik yaşamalarına yol açan unsurların tespit edilmesi ve sorunun en başta ortadan kaldırılması için önlemler alınabilir.

\section{ARTICLE INFO} ABSTRACT

\section{Keywords:}

Emotional labor

Burnout

Organizational identification

Mediating effect

Health personnel

Received 30 April 2020

Revised 15 January 2021

Accepted 5 March 2021
Purpose - In this study, it is aimed to determine the relationship between emotional labor behavior and burnout of health personnel and the mediating effect of organizational identification in this relationship.

Design/methodology/approach - Relational screening model was used in the research. The sample of the study consists of 784 healthcare professionals working in private bed hospitals affiliated to İstanbul Provincial Health Directorate Health Research Branch Directorate Private Bed Health Services Branch Directorate. SPSS package program was used for descriptive statistics, correlation analysis (s), validity and reliability tests and exploratory factor analysis. For confirmatory factor analysis, path analysis and mediating effect analysis, the SEM (AMOS) package program was used.

Results - According to the structural equation modeling results; It is seen that the dimensions of superficial behavior, deep behavior and natural behavior of emotional labor have an effect on the decrease in personal accomplishment, emotional exhaustion and depersonalization. On the other hand, it is seen that emotional labor has a profound effect on behavioral and natural behavior 
Article Classification:

Research Article dimensions on organizational identification. It is seen that organizational identification has an effect on the decrease in personal accomplishment, depersonalization and emotional exhaustion. Since the effect of superficial behavior on organizational identification was not detected, the mediating effect of organizational identification on the effect of burnout on decreased personal accomplishment, emotional exhaustion and depersonalization could not be tested. Organizational identification plays a full mediating role in the effect of deep behavior on the effect of burnout on a decrease in personal accomplishment, emotional exhaustion and depersonalization. Organizational identification plays a partial mediating role in the effect of natural behavior on the effect of burnout on a decrease in personal accomplishment and depersonalization, and a full mediating role in its effect on emotional exhaustion.

Discussion - The importance and value of the job and employees in the health sector should be taken into account. Because, healthcare personnel do not only work with physical and mental labor. In addition to these, they include their emotions as a labor factor in the process. Employees who are identified with their organizations are valuable for organizations. For this reason, the management should pay attention to the emotions and feelings of each healthcare provider as much as possible. In order for health personnel to be integrated with their organization, the management should clearly demonstrate its understanding and support for them. Thus, the responses of healthcare personnel (s) to various events and situations encountered in the work environment can be directly observed. Measures can be taken to identify the factors that cause healthcare personnel to experience burnout and to eliminate the problem in the first place.

\section{Giriş}

Günümüz çalışma dünyasında üretim işletmelerinden daha çok hizmet işletmelerinin oluşturduğu sektörlerin artan önemi, ulusal ekonomiye katkıları, istihdam olanaklarının fazlalığı gibi daha birçok neden hizmet sektörünü güçlü kılmaktadır (Zengin ve Erdal, 2000). Çok hızlı değişim ve gelişim alanına sahip olan hizmet sektörü; eğitim, konaklama, lojistik, sağlık gibi daha birçok alt alanı içermektedir. Değişimin ve gelişimin hızlı ve yoğun olduğu hizmet sektöründe rekabet de hemen hemen aynı yoğunluk düzeyinde ve zorlayıcı koşullarda kendini göstermektedir. Bu durumda örgütlerin sahip oldukları kaynakları olabildiğince etkin ve verimli kullanmaları kaçınılmazdır. İnsanın en değerli sermaye kaynağı olarak kabul edildiği ve emek yoğun bir sektör olan sağlık sektöründe de durum benzer şekildedir. Personelin başarısına ve refahına bağlı olarak örgütün başarısının da şekillendiği sağlık sektöründe insanlar arası etkileşim çok fazla yaşanmaktadır. Gerek kaliteli ve çözüm odaklı hizmet bekleyen müşteri (sektörde hasta olarak anılmaktadır) gerek etkililik, verimlilik ve karlılık beklentisi olan örgüt açısından çalışanların sahip olduğu fiziksel ve zihinsel yeterliliklerinin yanı sıra; duygularının önemi ve bunların doğru yönetimi ve sergilenmesi çalışanlarda aranan bir diğer temel özellik halinde gelmektedir.

Duygu olgusu, 1800'lü yıllardan bugüne kadar üzerinde çalışmalar yapılan ve çeşitli görüşler öne sürülen bir yapıdadır. İnsanın duygusunu ve hissini ele almak, bunların oluşmasına ve şekillenmesine neden olan kavramlar ve duyguların sonuçları üzerinde tahminler yürütmek yazında daima ilgi çeken bir alan olmuştur. Bu nedenle de gerek benzer gerekse farklı birçok duygu tanımına rastlamak olasıdır. Ancak, duygu kavramı, 1800'lü yıllardan bu yana özellikle de çalışma hayatında duyguların yeri, varlı̆̆ı, sergilenme biçimleri, örgütsel nedenleri ve sonuçları gibi birçok unsura bağlı olarak gittikçe önemsenen ve üzerinde tartışılan bir konu haline gelmiştir. Çalışma hayatında duygular ve bunların dışa vurulma biçimleri, bireyin işiyle alakalı hissettiklerini açıklamada kilit rol oynamaktadır. Bu nedenle de çalışma hayatında duygular çok farklı araştırma konularını da araştırmacılar için merak edilecek hale getirmektedir.

Bunların ötesinde, özellikle de son yıllarda giderek önemsenen bir konu olan duygusal emek, icra edilen işin birebir muhatabı bireylere veya müşteriye yönelik sergilenen davranışlardaki duygusal bileşenler veya bu davranışın arka planında yer alan unsurları incelemektedir. Çalışma hayatında duygunun başka bir boyutunu inceleyen kavram, çalışanın işini yapması sırasında gösterdiği davranışlarıyla karşı tarafa belli bir duygusal mesajın gönderilmesini sağlamayı amaçlamaktadır. Yaşanan bu durum da duyguların düzenlenmesinin artık bir iş gerekliliği olarak anıldığının bir göstergesi olduğunu anlatmaktadır. Yani, yapılan işi belli bir duygu ifadesiyle yapmak ve bunu yaparken de daha çok karşı taraftaki muhatabında bir duygu yaratabilme gayretiyle yapiyor olmak duygusal emek olarak ifade edilmektedir.

Kavram, ilk defa Hochschield (1983) tarafından "bir ücret karşılığında satılan ve değişim değeri olan, genel olarak gözlemlenebilir yüz (mimik) ve beden gösterimi oluşturmak için duyguların yönetilmesi" olarak tanımlanmıştır. Brotheridge ve Lee'nin (2003) duygusal emek tanımlamasına göre duygusal emek, çalışanların duygularını 
örgütün kalite, verimlilik, yüksek performans beklentilerine uygun olarak düzenleme çabalarıdır. İfadeden de anlaşılacağı gibi hizmet sektöründe istenen en önemli sonuçlardan biri olan kaliteyle duygusal emek davranışına yönelik stratejilere yönelim günümüz örgütlerinde giderek artmaktadır. Çünkü; müşterilerle kurulan iletişim, ortaya konulan hizmetin olmazsa olmaz bir parçasını temsil etmektedir. Sağlanan hizmet müşterinin memnuniyetinin önemli bir belirleyicisidir (Leidner, 1999). Bu durumda, çalışan tarafından sergilenen duygusal emek davranışı, hizmet kalitesini sağlayabilmenin temel ilkelerinden biridir demek de mümkündür. Daha çok üstlenilen rol gereğince çalışanın, örgütün ondan istediği bazı duyguları sergilemesi veya istemediği bazı duyguları bastırması ve hatta tamamen gizlemesine yönelik çabalarıdır (Seçer ve Tınar, 2004). Özellikle de sağlık sektöründe yapılan işin önemli bir parçası olarak kabul gören duygular, istenen davranışlar olarak dışa vurulduğunda hastayı ve hasta yakınlarını memnun edeceği gibi, öte yandan hissedilmediği halde varmış gibi sergileniyor olması da çalışanın bu durumdan memnuniyetsizlik duymasına ve zamanla psikolojik anlamda yıpranıp tükenmesine neden olabilmektedir. Çalışanlar tarafından duygusal emeğin etkin bir biçimde yönetilmesi, örgütün başarısını artırırken duyguların sergilenmesi esnasında yaşanabilecek en küçük bir zafiyet bile örgütün başarısızlığına yol açabilir (Basım ve Begenirbaş, 2012).

Çalışanların, örgütleri için en değerli unsurlar olduğu söylendiği halde onların memnuniyetsizliğiyle sonuçlanan davranışlar sergilemeye zorlanmaları duygusal emeğin bir ikilemi doğurduğunun önemli bir göstergesidir. Duygusal emeğin çalışan açısından bu gibi olumsuz sonuçlar doğurmasını ve uzun vadede yıkıcı etkilerini ortadan kaldıracak veya olumsuz sonuçları en aza indirecek nitelikteki öncüllerinin neler olduğuna bakılmasını gerekli kılmaktadır. Örgütsel özdeşleşme, bu değerli öncüllerden biridir. Tükenmişlik ile daha çok örgütsel bağlılık ilişkisi ele alınmış olup onlarca çalışma yapılmıştır (Moon ve Han, 2011; Soykan, 2012; Boymul, 2015; Nathan ve Herda, 2016; Tosun ve Ulusoy, 2017; Kaya, 2017; Zhou, vd., 2018; Dursun, 2019) örgütsel özdeşleşme ilişki üzerine yapılmış çalışma sayısı (Rode, Judge ve Sun, 2012; Lammers vd., 2013; Bitmiş, Sökmen ve Turgut, 2013; Yılmaz, 2014; Aypar, 2018; Köse, 2019) yok denecek kadar az sayıdadır. Oysaki örgütsel özdeşleşme psikolojik ve duygusal bir doyumu ifade etmekte ve bu sayede çalışanların da örgütleriyle bir bütün olmalarını sağlamaktadır. Oluşan bu bütünleşme ile çalışanın kendini adeta örgütüne adaması ile işinin içselleştirilmesi ve örgütsel verimlilik artacaktır. Çünkü insanın psikolojik bir canlı oluğu gerçeği yok sayılamaz. Örgütünü içselleştiren ve her şeyiyle benimseyen bir çalışan için dışardakilerin örgütü için ne düşündüğüne yönelik bir inancı vardır. Bu nedenle de her ne kadar işi sağlık sektöründe çalışan bireylerde olduğu gibi ağır psikolojik yıpranmaları içerse de bunu tolere etme kabiliyeti örgütüyle yaşanan özdeşleşme sayesinde olmaktadır.

Yukarıda bahsedilen ifadelere bağlı olarak, bu araştırma sonucunda, ülkemiz bünyesinde önemli bir çalışma sahası konumunda olan İstanbul ilinde bulunan özel sahipliği olan hastanelerde çalışanların örgütlerine yönelik özdeşleşmelerini nasıl değerlendirdikleri görebilmek, çalışanların sergilemekte oldukları duygusal emek davranışları ve bunları belirlerlerken hangi davranış düzeyinde (yüzeysel, derinden ve doğal davranış) olduklarını tespit edebilmek, çalışanların duygusal emek davranışlarına bağlı olarak tükenmişlik düzeyleri (kişisel başarı hissinde azalma, duygusal tükenme ve duyarsızlaşma) arasında bir ilişkinin olup olmadığını ve hatta aranan bu ilişkide örgütleriyle yaşanan özdeşleşme düzeylerinin aracilık rolü oynayıp oynamadı̆̆ 1 görebilmek gibi kıymetli bulgulara erişmek amaçlanmaktadır. Bu nedenle, bu üç değişkenin bu araştırmanın örneklemini oluşturan özel hastanelerde çalışanlar üzerinde ilk defa ele alınıyor olması ve aralarındaki olası ilişkilerin yapısal eşitlik modellemesiyle test edilmesi bakımından yazında var olan boşluğu bir nebze de olsa doldurmada önemli bir katkı sunabileceği düşünülmektir.

\section{KAVRAMSAL ÇERÇEVE}

\subsection{Duygusal Emek}

Çalışma yaşamının tıpkı sosyal yaşam gibi küreselleşmesiyle birlikte örgütlerin faaliyetlerinde insan ilişkileri önemli bir hal almıştır. Bu durum da hizmet sektörünün ekonomik faaliyetlerde sahip olduğu payın artmasına olanak sunmuştur. Hizmet sektörünü ve bu sektörde elde edilen kaliteyi üretim sektöründen ayıran temel nokta, bireylerarası ilişkiler üzerine kurulu olmasıdır. Çünkü; hizmet sektöründeki örgütler yalnızca hizmet sunmamakta aynı zamanda sunulan hizmetleri karşı tarafa saygılı, güler yüzlü ve anlayışlı bir tavır takınarak göstermektedir. Bu durumda da örgütler, bahsi geçen hizmetin icra edilmesinin öncesinde, esnasında ve sonrasında hizmet kalitesinden ödün vermemek amacıyla birtakım kurallar belirlemekte ve çalışanlarının da bu kurallara riayet etmelerini istemektedir. Bunun için de gerekli kontrolleri ve denetlemeleri yapmaktadırlar. Burada karşımıza çıkan unsur ise duygusal emektir. Örgütler tarafından belirlenen kurallara göre çalışan 
personellerin duygusal ifadelerini veya hissettiklerini değiştirmek ve düzenlemek şartıyla harcadıkları çabaya duygusal emek adı verilmektedir. Kavram, Hochschild'ın (1983) havayolu taşımacılık sektöründe yapmış olduğu araştırmalar neticesinde, duygularıyla ilgili davranışlarının ücret karşılığında çalışmakta olanların önemli bir parçası olduğunu öne sürmesiyle yazında kendine yer edinmeye başlamıştır (Çoruk, 2014). Yüz ve bedenle ilgili gösterimleri oluşturan hislerin yönetimi olan duygusal emek (Diefendorff vd., 2005), yüz yüze ilişkilerin kurulduğu işlerde önemli bir yere sahiptir (Chau vd., 2009). Grandey'e $(1999,2000)$ göre duygusal emek, bir düzenleyicidir. Yani örgütün amaçları doğrultusunda çalışanların hem duygularının hem de duyguların dışa vurulmasının düzenlemesi sürecinin bir bütünüdür.

Hochschild'a göre, duygusal emek gerektiren işlerin üç temel özelliği vardır. Birinci özellik, çalışanın yapmakta olduğu işte; hasta, öğrenci, misafir, çocuk gibi diğer bireylerle olan yüz yüze veya karşılıklı konuşma içeren etkileşimlerinin geniş ve önemli bir yere sahip olmasıdır. İkinci özellik, çalışanların sergiledikleri duygusal davranışlarının diğer insanların duygularını etkileyebilmek, yönlendirebilmek ve hatta değiştirebilmek amacı taşımasıdır. Üçüncü özellik de çalışanlar tarafından işin bir parçası olarak sergilenen duygusal davranışların örgüt tarafından belirlenen kurallar içinde yer alıyor olması ve bunların örgüt tarafından denetlenmesidir. Çünkü örgütün belirlediği çerçeve örgütün misyon açıklamasında ve kültürel değerlerinde kendine yer bulmaktadır (Seery ve Corrigall, 2009).

Duygusal emek konusunda Hochschild'dan sonra ve nispeten ondan farklı görüşler ortaya koyan araştırmacılar olmuştur. Ashforth ve Humphrey (1993), hizmet alanların gözlenebilen davranışlardan doğrudan etkilendiğini ve çalışanların da kendi duygularını sergilemeden de onlardan istenen duygusal davranışları yerine getireceklerini belirtmişlerdir. Yani, davranışın arkasındaki duygulardan çok; sergilenen davranışın niteliğine vurgu yapmışlardır (Yürür ve Ünlü, 2011). Duygusal emeğe başka bir yaklaşımla bakan araştırmacılardan Morris ve Feldman (1996) da etkileşimci yaklaşıma dikkat çekmişlerdir. Çalışanların işlerini icra etmeleri sırasında çevresel koşulların etkisi altında olduklarını belirtmişlerdir. Duygusal emeğin çalışanların içinde oldukları koşullara bağlı olarak davranışlar sergileyebilmeleri için sahip olmaları gereken planlama, kontrol etme ve beceri düzeylerinin bütünleşmesi gerekliliğini öne sürmüşlerdir (Yürür ve Ünlü, 2011).

Tüm bu açılamalara bakıldığında duygusal emek kavramının hem istenilen duyguları yansıtma hem de istenmeyen duyguları bastırma olarak iki yönlü bir şekilde değerlendirilmesi gerektiği anlaşılmaktadır. Bu çift yönlü değerlendirmeye göre duygusal emek davranışlarının sergilenmesinde tek bir davranışın olamayacağı da açıktır. Duygusal emek, yüzeysel davranış, derinden davranış ve doğal (samimi) davranış olmak üzere üç farklı tür duygusal emek davranış düzeyinde incelenmektedir (Diefendorff, vd., 2005; Ashforth ve Humphrey, 1993; Özgen, 2010).

Yüzeysel davranış; çalışanın işini yaptığı esnada hissetmiyor olsa bile ondan beklenen duyguları, dış görünüşünde yaptığı bazı değişikliklerle (ses tonu, jest, mimik, vb.) sergilemesidir. Ancak, çalışanın böyle davranıyor olması onun işiyle bütünleşmediği ya da işiyle alakalı hiçbir hisse sahip olmadığı anlamı taşımamaktadır. Yüzeysel davranış sergilenmesinde, çalışanın etrafa gösterdiği duygular, hissettiklerinden farklılaşarak yansımaktadır (Ashforth ve Humphrey, 1993; Chu ve Murrmann, 2006).

Derinden davranış; çalışanın örgütü tarafından belirlenen kurallara bağlı kalarak sergilemesi gereken duyguları gerçekten kendisinin de hissetmeye çalışmasıdır (Grandey, 2003). Bu davranış türünde duygular aktif hale gelerek beklenen davranış için birey teşvik edilmektedir. Bu sayede de bireyin duygularının bastırılarak veya şekillendirilerek dışa vurulması sağlanır. Hochschild bu davranışın, i) bireyin gerçekte var olan hislerini, bir duyguyu uyandırmak veya bastırmaya çalışmak amacıyla uyarması, ii) bireyin hayal gücünü, karşı karşıya kaldığı olay veya konu özelinde gereken duyguyu hissetmek üzere kendi kafasında fikir, düşünce ve hatıraları kullanarak canlandırmaya çalışması yoluyla yönetmesi olmak üzere iki şekilde olacağını savunmaktadır.

Yüzeysel davranış, çalışanın dışa dönük ve doğrudan gözlemlenebilen davranışlarının üzerinde dururken; derinlemesine davranış ise, çalışanın iç dünyasında olanlara odaklanmaktadır. Burada dikkat edilmesi gereken, her iki durumda davranışın gözlemlenebilir hal aldığında birinde duyguların değiştirilmesiyle düzenlenmiş olduğunun bilinmesidir (Ashforth ve Humphrey, 1993).

Hochschild'a göre çalışanlar, bu iki duygusal emek davranışından birine yönebilirler. Yönelimlerine göre davranış sergileyebilirler (Grandey, 2000). Hochschild'ın görüşüne göre, hizmet sunan çalışan az veya çok 
düzeyde bilinçli olarak kendi duygularının yönetiminde aktif rol oynamaktadır. Fakat, burada fark edilmeyen önemli bir nokta vardır. Çalışanın bir insan olduğu, yalnızca örgütsel kurallar çerçevesinde hareket etmeyeceği, psikolojik bir canlı olduğu hesaba katılmamaktadır. Oysa ki her çalışan bir bireydir ve ondan beklenen duyguları doğal bir şekilde ve içtenlikle yaşıyor olması ve sergilemesi de olağandır. Örneğin hastaneye getirilen yaşlı ve yaralı bir insana duygusal bir tepki vermesi o çalışanın illa çaba sarf etmesini gerektirmez. Çünkü o çalışanın mağdur, yardıma muhtaç ve kendisinden zayıf birine rol yaparak davranış sergilemesine ihtiyacı yoktur. Bu sebeple de Ashforth ve Humphrey (1993), çalışandan sergilemesi beklenen duyguların samimi ve içten bir biçimde hissedilmesi ve hatta bunun doğrudan muhatabına, çevresine yansıtılmasını doğal (samimi) davranış olarak tanımlanmaktadır. Bu davranış şekli de duygusal emeğin üçüncü alt boyutu olarak kabul edilmektedir (Kruml ve Geddes, 2000).

\section{2. Örgütsel Özdeşleşme}

Örgütler için en değerli sermaye unsuru olan insan, birey olarak kendini eşsiz bir varlık olarak kabul etmektedir. Ancak her ne kadar bireysel değerini vurgulasa da insanoğlu sosyal bir canlıdır ve yaşamına uzun vadede tek başına devam edememektedir. Bu nedenle de "ben kimim?" sorusuna bir cevap bulmak gayretiyle ilk başta yakın çevresine yönelmektedir. İnsanın sosyal bir canlı olmasından kaynaklanan bu arayış hali, kendisine benzer nitelikteki insanların, kendi değerlerine ve ihtiyaçlarına benzer nitelikteki unsurların olduğu insanlara, yapılara ve oluşumlara yönelimlerle grupların oluşumu başlamaktadır. Ancak, oluşan bu gruplardan hangisine dahil olacağı ve daha sonrasında da ait olacağı gruplar arasında yapılan kıyaslamayla mümkün olmaktadır. Yani birey bu kıyaslamayı özel ve iş yaşamında yapabileceği için değerler uyumlaşmasına bakmaktadır. Örgütsel anlamda yapılan bu ayrıştırmayla birey, kendisini örgütünden ayrılmaz bir parça olarak görüp, Sosyal Kimlik Teorisi'nin bir uzantısı olan özdeşleşmeyi, bir grubun üyesi olma, o gruba yüksek aidiyet hissetme, deyim yerindeyse o grup içinde bireyin kendisini tıpkı ailenin bir üyesi gibi hissetmesiyle örgütsel özdeşleşme ortaya çıkmaktadır (Van Dick vd. 2004). Yaşanan yüksek düzeydeki duygusal bağlılığı ve aidiyeti içeren örgütsel özdeşleşme, çalışanın kendi kimliği ve değerleriyle örgütün kimliği ve değerlerinin uyumlaşmasını öne çıkarmaktadır (Hall vd., 1970). İşcan'ın (2006) da belirttiği gibi örgütsel özdeşleşme, bireyin örgütüne karşı benliğinin, tutumunun ve davranışlarının temelini oluşturması nedeniyle önemlidir. Çünkü, çalışanla örgütü arasında kurulan bilişsel ve psikolojik bağın gücü, çalışanın motivasyonuna ve performansına katkı sağlayacağı için dahil olunan grubun amacının, değerinin ve varlık sebebinin çalışanınkiyle örtüşüyor olması gerekmektedir (Van Knippenberg, 2000). İfadelerden de anlaşılacağı gibi, herhangi veya geçici süreli bir iş birliği sağlamadan çok daha önemli bir oluşumdan bahsedilmektedir.

Örgütsel özdeşleşme, örgüt içinde birlik içinde olmaya imkân veren bir ortaklık duygusunu çalışana kabullendirmekte ve içselleştirmektedir (Gossett, 2002). Cheney'in (1983) vurguladığı gibi, sağlanan bu içselleştirme sayesinde örgütsel özdeşleme, örgütler için bir sürecin sonunda elde edilen değerli bir üründür. Bireyin kendini bulma çabasıyla sorduğu sorudan (ben kimim?) biz olma düşüncesine evrilmesi sayesinde, çalışanın örgütünü yalnızca maddi kazanç sağladığı bir yer değil, benliğini tanımlayabildiği, yoğun ve kalbi duygular beslediği ailesi gibi içselleştirebilmesidir (Riketta, 2005). Bu sayede de çalışan, örgütüne yönelik övgüyü ve/veya şikâyeti bireysel olarak sahiplenmekte ve buna göre iyileştirmeye, sorunlara çözüm aramaya çabalamaktadır. Örgütsel özdeşleşme, çalışanın örgütüne yönelik yoğun bir sadakat içinde olma halini ifade ettiği için, çalışanın örgütüyle benzer ve çoğu defa da aynı duygulara sahip olması gerekliliği düşüncesini öne çıarmaktadır. Buna bağlı olarak da birlikte ve bütünlük içinde hareket edilmesi gerekliliği gayesiyle, nitelikli kararlar alıp uygulamaya geçebilmede oldukça etkilidir (Ashforth vd. 2008). Çünkü, bireyin kendi benliğini tanımlarken sağladığı birlik ve beraberlik duygusuyla hareket edilmektedir. Adanmışlığı ve yoğun bir bağlılığı ifade etmeye çalışan benlik yapısı, Katrinli ve meslektaşlarının (2008) da ifade ettiği üzere örgütsel özdeşleşme, örgüt üyelerinin kendi aralarında uyumlu ve bütünün birer parçası oldukları bilinciyle bütünlük sağlayabilmeleri için kilit bir unsurdur. Bunun yanı sıra, örgütsel özdeşleşme örgüt içinde yaşananların niteliğine bakılmaksızın derin bir kabullenme halidir ve çalışanın örgütüne karşı beslediği olumlu, kabullenici ve yapıcı duygu durumlarını ölçme ve değerlendirme çabasıdır (Mael ve Ashforth, 1995).

\subsection{Tükenmişlik}

Christina Maslach tarafından geliştirilmiş olan tükenmişlik kavramı, "işi gereği yoğun duygusal taleplere maruz kalan ve sürekli diğer insanlarla yüz yüze çalışmak durumunda olan kişilerde görülen fiziksel bitkinlik, uzun süreli 
yorgunluk, çaresizlik ve umutsuzluk duygularını yapılan işe, hayata ve diğer insanlara karşı olumsuz tutumlarla yansitılması ile oluşan bir sendrom"dur (Maslach ve Zimbardo, 1982; Maslach vd., 2001; Aktaran: Sürgevil, 2006: 7) ifadesiyle açıklanmaktadır. İfadeden de anlaşılacağı üzere tükenmişlik, çalışma ortamıyla çalışanın birebir etkileşimi sonucunda ortaya çıkmaktadır. Çalışanın fiziksel ve/veya ruhsal sağlığının ve enerjisinin kötüleşmesi ve tükenmesini anlatan kavram, 1970'li yıllardan günümüze kadar halihazırda önemli bir sosyal sorun olarak ele alınmaktadır (Budak ve Sürgevil, 2005). Köse ve Gölova'nın (2006) da üzerinde durarak belirttiği gibi, özellikle hizmet sektöründeki çalışma alanlarında (eğitim, sağlık, havacılık, sosyal hizmet, vd.) yoğunlukla karşılaşılan bir durum olan tükenmişlik, örgüt içindeki iş stresinden kaynaklanmaktadır. Fakat, tükenmişliğin diğer örgütsel kaynaklı stres türlerinden ayrılan noktası, çalışanların işleri gereğince diğer bireylerle (hasta, müşteri, yaşlı, çocuk, vb.) sıklıkla, birebir ve yoğun bir biçimde iletişim ve etkileşim içinde olmalarıdır (Akça, 2008). Çalışan ve hizmet alanların iç içe olması halinin ve tükenmişlik tanımlamasının birlikte ele alınmasıyla; tükenmişliğin çalışan ve hizmet alan taraflarla olan iletişiminin çalışan için duygusal bazı yükümlülükler doğurduğunu anlatmaktadır.

Tükenmişlik; geçici bir yorgunluk veya zorlanma değil, bireyin işinden soğumasıyla sonuçlanan kalıcı bir durumdur (Avşaroğlu vd., 2005). Tükenmişlik, iş stresi nedeniyle ortaya çıkmakla beraber iş stresinin bir belirtisi değil; iş stresinin etkin bir şekilde yöneltilmesinin bir sonucudur (Basım vd., 2011). Tükenmişlik, mesleki bir tehlike olarak nitelendirilen ve başarısız olma, yıpranma, aşırı yüklenme sonucu güç ve enerji kaybı veya karşılanamayan ya da karşılanmayan istekler nedeniyle bireyin iç kaynaklarında tükenme olarak ifade edilmektedir (Çelik ve Turunç, 2011). Tükenmişliğin; beklentiler, tutumlar ve algılamalar içeren ve kişisel düzeyde ortaya çıkan, içsel psikolojik bir yaşantı olduğu kabul görmektedir (Üngüren vd., 2010). Tükenmişlik, ağır ve ciddi sonuçları beraberinde getireceği için örgüt ve birey açısından üstesinden gelinmesi ve hatta önlenmesi gerekmektedir.

Maslach ve Jackson (1981), tükenmişlik kavramını duygusal tükenme, duyarsızlaşma ve kişisel başarı hissinde azalma olarak üç boyutta ele almışlardır. Sırasıyla bu boyutlara baktığımızda; duygusal tükenme, çalışanların fiziksel yorgunluklarının ötesinde duygusal olarak yorulmaları ve hatta yıpranmalarındaki artış ifade etmektedir (Ergin, 1992; Budak ve Sürgevil, 2005, Yıldırım ve İçerli, 2010). Çalışanın duygusal kaynaklarının fazlasıyla zorlanmış ve bunun sonucunda da bitmiş olmasının anlatılmaya çalışıldığı bu boyutta, örgütteki iş yükündeki aşırılık ve çalışanlarla, hizmet sağlanan taraflarla yaşanan çatışmaların doğurduğu sonuçları ele alınmaktadır. Çalışanın yeni başlayan günden umudunun; yeni bir insanla karşılaşıp onunla yüzleşebilecek isteğinin ve enerjisinin olmaması gibi oldukça önemli belirtileri olan duygusal tükenmenin bir diğer sonucu da bireyin kendini toparlayıp eski psikolojik gücüne kavuşacak enerjiye sahip hissetmemesidir (Maslach and Goldberg, 1998). Bu durumda da çalışan hem kendisine hem de çevresine karşı negatif yüklü olmaktadır (Yıldız, 2015). Duygusal tükenme, tükenmişliğin bireysel düzeydeki stres boyutunu temsil etmektedir (Maslach and Goldberg, 1998) ve tükenmişliğin diğer iki alt boyutu olan duyarsızlaşma ve kişisel başarı hissinde azalmaya kıyasla daha açık gözlemlenebilen boyutudur (Yıldız, 2015).

Duyarsızlaşma; çalışanın, hizmet sunduğu bireylere karşı ilgisiz tavır takınması, negatif ve yıkıcı duyguları yansıtması olarak tanımlanabilir. Çalışanın muhatabı olan bireylere birer nesne gibi davranması, onları sinıflandırması ve onlarla arasına mesafe koyarak onlara karşı umursamaz ve hatta alaycı bir tavır sergilemesidir (Üngören vd., 2010). Duyarsızlaşmanın temel nedeni; çalışanın idealizm kaybına uğramasıdır. Yani; icra etmekle yükümlü olduğu işi için hizmet sağladığı tarafa insan muamelesi yapmıyor olmayı ifade etmektedir. Tükenmişliğin bir alt boyutu olan duygusal tükenmenin varlığıyla kendini gösteren duyarsızlaşma, çalışanın kendi kendini adeta bir koruma altına alarak tampon bölge oluşturma çabasını temsil eder (Maslach and Goldberg, 1998). Çalışan tarafından geliştirilen bu tampon bölge sayesinde çalışan, çevresine yönelik oldukça kayıtsız bir tutum oluşturmaktadır. Devamlılığı olan bu kayıtsız tutum neticesinde de çalışan duygusal olarak işinden ve işinin gerekliliklerinden de uzaklaşma yaşamaktadır (Yıldız, 2015). Çünkü, çalışan tarafından; çevresi ve hizmet sağladığı taraf olan diğer bireylerle yaşadığı etkileşim ve iletişimde ilişkilerin en alt seviyeye indirilmesi ve kalıplaşmış ifade ve davranışlarla hareket edilmesi gerçekleştirilir. İşinin gerekliliklerine bağlı olarak karşılaştığı taraflara adeta birer nesneymiş gibi davranışlar sergilenmesi kendini göstermektedir. Gittikçe artan ilgisiz, soğuk, katı ve hatta insani sayılamayacak düzeydeki yapı duyarsızlaşmanın açık bir göstergesi haline gelmektedir (Basım ve Şeşen, 2006). Maslach and Goldberg 'in (1998) de belirttiği üzere; tükenmişliğin kişilerarası boyutunu temsil eden duyarsızlaşma, kişiler arasında yaşanan ilişkilerdeki bozulmaların yalnızca bireysel düzeyde kalmayıp ilerleyen süreçte örgütsel bir 
sorun haline geleceğinin de önemli bir habercisidir (Polatçı, 2007).

Kişisel başarı hissinde azalma; çalışanın işiyle alakalı yeteneğinin ve bu yeteneğine bağlı etkililiğinin ve verimliliğinin düştüğüne yönelik inancı olan kişisel başarı hissinde azalma, bireyin kendisini için olumsuz değerlendirme yapmasındaki eğilimini ifade etmektedir (Budak ve Sürgevil, 2005, Yıldırım ve İçerli, 2010). Kendisinden işle ilgili talep edilenleri yerine getirmede yetersiz kaldığı inancının hâkim olmasından dolayı bireyin işinde ilerleyebilmesi ve sosyal destek almasında eksiklik yaşadığına dair duygusunu ve inancını güçlendiren kişisel başarı hissinde azalma, bireyi hizmet sağladığı bireylere yardım etmeyle ilgili kendini yetersiz görmeye ve hatta yetersizliği nedenliyle onlara zarar verdiği düşüncesine sevk edebilir. Tükenmişliğin bireyin kendi kendini değerlendirme boyutu olan bu alt boyut, çalışanın kendini suçlamasına ve yetersizliğine vurgu yapmaktadır (Maslach and Goldberg, 1998).

\subsection{Kavramlar Arasındaki İlişkiler}

Günümüz çalışma yaşamında yöneticilerin örgütlerini idare edebilmeleri ve çalışanlarına sağlıklı bir çalışma ortamı sunabilmeleri için yalnızca prosedür ve kurallar yeterli değildir. Nitekim çalışma dünyasındaki yoğun rekabet ve yaşanan hızlı değişimler, çalışanları sadece birer bilgi emekçisi olmaktan öteye taşımıştır. Özellikle de hizmet sektöründeki örgütlerde bunun yanında bir de duygusal emekçiler olmaları gerekmektedir. İnsanın duygusal yönünü davranışlara dökmesini ifade eden duygusal emek de bu olmazsa olmaz unsurlardan biridir. Yüzeysel davranıştan doğal (samimi) davranış sergilemeye kadar değişim gösterebilen duygusal emek, insan psikolojisinin de bir yansımasıdır. Aynı zamanda da bilişsel bir süreci de içererek etkin karar verebilmeye de etki etmektedir. Bireyin işini icra ederken karşılaşabileceği belirsizlik hali, yaşayabileceği çatışma ve özellikle de sağlık sektöründe üstlenilen yüksek sorumluluk gibi benzeri durumlarda duygularını ortaya koyarken kendisini kontrol ederek ve/veya edemeyerek gerçekleşmektedir. Örgütleriyle yaşadıkları bilişsel ve duygusal bütünlük hali olan örgütsel özdeşleşme, burada devreye girerek kendini göstermektedir.

Örgütleriyle özdeşleşme yaşayan bireyler, çalıştıkları örgütün dışındaki ortamlarda ve durumlarda kendilerini o örgütün birer temsilcisi olarak kabul ederler (Miller, vd., 2000). Bundan dolayı da davranışlarında bilişsel yansımalar görülecektir. Bu da duygusal emeğin bir göstergesidir. Örgütün yönetim kademelerince belirlenmiş olan amaçlara ve hedeflere bağllık göstererek performans sergilemek isteyeceklerdir. Çünkü yaşanan örgütsel özdeşleşmede örgütün menfaatlerini bireyselleştirip içselleştirme söz konusudur. Örgütüyle özdeşleşme yaşayan bir çalışan kuşkusuz ki örgütün içinde ve dışında örgütüyle gurur duymakta ve onu sahiplenerek örgütüne sayg1 göstermektedir (Cilasun, 2016). Örgütlerde özdeşleşme yaşanabilmesinin etkin hale getirilmesiyle düşük iş devir oranı, işten ayrılma niyeti ve tükenmişlik gibi çok önemli sonuçlar elde edilecektir (Yeşiltaş vd., 2012). Örgütsel özdeşleşmenin verimlilik artışının bir öncülü olduğu da tartışmasız bir gerçektir. Fakat bu verimliliği yalnızca somut ve maddesel getiriler olarak görmek eksik kalmaktadır. Örgütünü sahiplenen çalışanların olduğu bir çalışma ortamında psikolojik iyi oluşlar ve sahiplenme duyguları da önemli birer verimlilik göstergesidir. Bu sayede "ben" kavramının ötesinde bütünleştirici gücü olan "biz" ortaya çıkmaktadır (Polat, 2009). Örgütsel özdeşleşme yaşanması halinde birey kendini daha iyi hissedecektir ve bu da özgüvenini artırarak tükenmişliğin kişisel başarı hissinde azalma alt boyutuna etki ederek tükenmişliği azaltacaktır. Köse' nin (2019) ifade ettiği üzere, örgütsel özdeşlemenin aktif olarak fiilen alt kademede çalışan personellerde daha net gözlemlendiği bilgisiyle sağlık sektöründeki personellerde örgütlerine sadakat gösterme, duygu durumlarını düzenleme ve örgütün kurallarına itaat etme rahatlıkla görülecektir (Şahin, 2014). Tüm bunların ötesinde, örgütsel özdeşleşmenin özellikle özel sektörde rekabet eden örgütlerde önemli bir yeri ve anlamı vardır. Çünkü her örgüt kendisini benzer nitelikteki örgütlerle mukayese etme ve mümkün oldukça da onlardan kendini ayrıştırarak öne çıkarma gayreti içerisindedir. Bireylerin bütününün birer temsili olan örgütler, yoğun rekabet koşullarında pes etmeyen, duygularını ve davranışlarını adeta kendisi gibi aktaran ve işini, örgütünü benimseyen personellere ihtiyaç duyarlar. Uray'ın (2014) da belirttiği gibi burada yöneticilere ciddi görevler düşmektedir. Örgüt yöneticileri, örgütün politikalarını ve kurallarını rasyonel düzeyde hazırlayarak çalışanların duygularına hitap edebilmelidirler. Duygusal emek davranışlarının sergilenmesi gereken sağlık sektöründe bu daha da ön planda tutularak Mael ve Ashforth'un (1992) özellikle vurguladığı ailenin bir parçası gibi hissedilme olan örgütsel özdeşleşme için ortam hazırlanmalıdır.

Duygularını düzenleme kabiliyetine sahip çalışanlarda psikolojik yıpranma olan tükenmişlik farklı düzeylerde görülecektir. Hochschild (1983) yüzeysel davranış sergilemenin çalışanları duygusal anlamda 
tükenmişliğe karşı koruduğunu ifade ederken, bazı araştırmacılar (Morris ve Feldman, 1997; Grandey, 1999) ise duygusal tükenme ve yüzeysel davranış arasında pozitif ilişki olduğunu ileri sürmüşlerdir. Araştırmaya konu olan duygusal emek, örgütsel özdeşleşme ve tükenmişlik ilişkisinde örgütsel özdeşleşmenin tükenmişlik üzerindeki etkileri yazında çok da net değildir. Örgütsel özdeşleşmenin tükenmişlik arasında negatif yönlü ilişki olduğunu belirten çalışmalar (Rode vd., 2012) olsa da aralarında anlamlı ilişkinin olmadığını öne süren çalışmalar da mevcuttur (Lammers vd., 2013). Bunların yanı sıra, örgütüyle kendini özdeşleştiren çalışanların daha sıkı çalışacağı (Tompkins ve Cheney, 1985; Ashforth vd., 2008) ve bundan dolayı da kaçınılmaz olarak daha fazla tükenmişlik duygusu (Maslach vd., 2001) yaşayabilecekleri de söylenmektedir. Öte yandan duygu durumunun emek sergilerken kendini göstermesi de örgütle özdeşleşme ve tükenmişlikle birebir ilişkilendirilmektedir. İçten gelen ve samimi duygularla iş yapan personeller, yaptığ işten keyif alacak ve bu sayede de örgütün ona sağladığı koşullar sayesinde örgütsel özdeşleşme yaşayabilecektir. Karşılaşılan her zorluk için çözümler üreterek bunları fırsata dönüştürerek daha az tükenmişlik yaşayacaktır. Tüm bu ifadelerin ötesinde ise örgütsel özdeşleşmenin birey ve örgüt düzeyinde olumsuz etki oluşturması da mümkündür. Örneğin; örgütüyle yüksek düzeyde özdeşleşme yaşayan bir çalışanın örgütsel özdeşleşme yaşamayan bir çalışana kıyasla yaşadığı tükenmişlik düzeyinin daha da fazla gözlemlenmesi de olasıdır (Kreiner ve Ashforth 2004). Çünkü çalışanda, örgütsel dayatmaları, sıkı politikaları ve örgütün hatalarını görememe hali gelişebilecektir. Burada da karşımıza örgütsel özdeşleşmenin aracılık rolünün olup olmadığ1 çıkarmaktadır.

\subsection{Araştırmanın Amacı ve Hipotezleri}

Bu çalışmada sağlık personellerinin duygusal emek davranışı ve tükenmişlikleri arasındaki ilişki ve bu ilişkide örgütsel özdeşleşmenin aracılık etkisinin tespit edilmesi amaçlanmaktadır. Bu temel motivasyondan hareketle oluşturulan diğer hipotezler ise aşağıda sıralanmaktadır.

$\mathrm{H}_{1}$ : Özel hastanelerde çalışan sağlık personellerinin yüzeysel davranışının kişisel başarı hissinde azalmaya etkisi vardır.

$\mathrm{H}_{2}$ : Özel hastanelerde çalışan sağlık personellerinin yüzeysel davranışının duygusal tükenmeye etkisi vardır.

$\mathrm{H}_{3}$ : Özel hastanelerde çalışan sağlık personellerinin yüzeysel davranışının duyarsızlaşmaya etkisi vardır.

$\mathrm{H}_{4}$ : Özel hastanelerde çalışan sağlık personellerinin derinden davranışının kişisel başarı hissinde azalmaya etkisi vardır.

$\mathrm{H}_{5}$ : Özel hastanelerde çalışan sağlık personellerinin derinden davranışının duygusal tükenmeye etkisi vardır. $\mathrm{H}_{6}$ : Özel hastanelerde çalışan sağlık personellerinin derinden davranışının duyarsızlaşmaya etkisi vardır.

$\mathrm{H}_{7}$ : Özel hastanelerde çalışan sağlık personellerinin doğal davranışının kişisel başarı hissinde azalmaya etkisi vardir.

Hs: Özel hastanelerde çalışan sağlık personellerinin doğal davranışının duygusal tükenmeye etkisi vardır.

H9: Özel hastanelerde çalışan sağlık personellerinin doğal davranışının duyarsızlaşmaya etkisi vardır.

$\mathrm{H}_{10}$ : Özel hastanelerde çalışan sağllk personellerinin yüzeysel davranışının örgütsel özdeşleşmeye etkisi vardır.

H11: Özel hastanelerde çalışan sağlik personellerinin derinden davranışının örgütsel özdeşleşmeye etkisi vardır.

$H_{12:}$ Özel hastanelerde çalışan sağlık personellerinin doğal davranışının örgütsel özdeşleşmeye etkisi vardır.

$\mathrm{H}_{13}$ : Özel hastanelerde çalışan sağlık personellerinin örgütsel özdeşleşmesinin kişisel başarı hissinde azalmaya etkisi vardır.

$\mathrm{H}_{14}$ : Özel hastanelerde çalışan sağlık personellerinin örgütsel özdeşleşmesinin duygusal tükenmeye etkisi vardır.

H15: Özel hastanelerde çalışan sağlık personellerinin örgütsel özdeşleşmesinin duyarsızlaşmaya etkisi vardır. H16: Özel hastanelerde çalışan sağlık personellerinin yüzeysel davranışının kişisel başarı hissinde azalmaya etkisinde örgütsel özdeşleşmenin aracılık rolü bulunmaktadır.

$\mathrm{H}_{17}$ : Özel hastanelerde çalışan sağlık personellerinin yüzeysel davranışının duygusal tükenmeye ilişkisinde örgütsel özdeşleşmenin aracılık rolü bulunmaktadır.

H18: Özel hastanelerde çalışan sağlık personellerinin yüzeysel davranışının duyarsızlaşmaya etkisinde örgütsel özdeşleşmenin aracılık rolü bulunmaktadır

H19: Özel hastanelerde çalışan sağlık personellerinin derinden davranışının kişisel başarı hissinde azalmaya etkisinde örgütsel özdeşleşmenin aracılık rolü bulunmaktadır.

$\mathrm{H}_{20}$ : Özel hastanelerde çalışan sağlık personellerinin derinden davranışının duygusal tükenmeye etkisinde 
örgütsel özdeşleşmenin aracılık rolü bulunmaktadır.

$\mathrm{H}_{21}$ : Özel hastanelerde çalışan sağlık personellerinin derinden davranışının duyarsızlaşmaya azalmaya etkisinde örgütsel özdeşleşmenin aracılık rolü bulunmaktadır.

$\mathrm{H}_{22}$ : Özel hastanelerde çalışan sağlık personellerinin doğal davranışının kişisel başarı hissinde azalmaya etkisinde örgütsel özdeşleşmenin aracılık rolü bulunmaktadır.

$\mathrm{H}_{23}$ : Özel hastanelerde çalışan sağlık personellerinin doğal davranışının duygusal tükenmeye etkisinde örgütsel özdeşleşmenin aracılık rolü bulunmaktadır.

$\mathrm{H}_{24}$ : Özel hastanelerde çalışan sağlık personellerinin doğal davranışının duyarsızlaşmaya etkisinde örgütsel özdeşleşmenin aracılık rolü bulunmaktadır.

\section{YÖNTEM}

Yukarıda yapılan açıklamalara binaen araştırmanın temel motivasyonu; özel hastanelerde çalışan personellerin duygusal emek davranışı ve tükenmişlik arasındaki ilişki: örgütsel özdeşleşmenin aracılık etkisini sorgulamaktır.

\subsection{Araştırmanın Modeli}

Araştırmada, birden fazla değişkenin birbiriyle olan olası ilişkilerinin varlığının sorgulanması amacıyla hazırlanan anket formlarıyla araştırıldığı ilişkisel tarama modeli kullanılmıştır (Karasar, 2012; Büyüköztürk vd., 2012). İlgili modeli oluşturmak için duygusal emek davranışı, örgütsel özdeşleşme ve tükenmişlik ölçekleri kullanılmıştır. Araştırmanın amacına ve belirlenen 24 hipoteze uygun olarak geliştirilen araştırmanın kavramsal modeli aşağıda (Bkz.: Şekil 1) verilmiştir. Araştırmanın kavramsal modeline göre, var olan iki değişken arasındaki ilişkinin modele yeni bir değişkenin eklenmesiyle oluşan aracılık rolünün tespitine yönelik bir model olduğu anlaşılmaktadır (Arı, vd. 2010). Bu ilişkiler çerçevesinde hazırlanan modelde duygusal emek (bağımsız değişken), örgütsel özdeşleşme (aracı değişken) ve tükenmişlik (bağımlı değişken) değişkenler olarak ele alınmıştır.

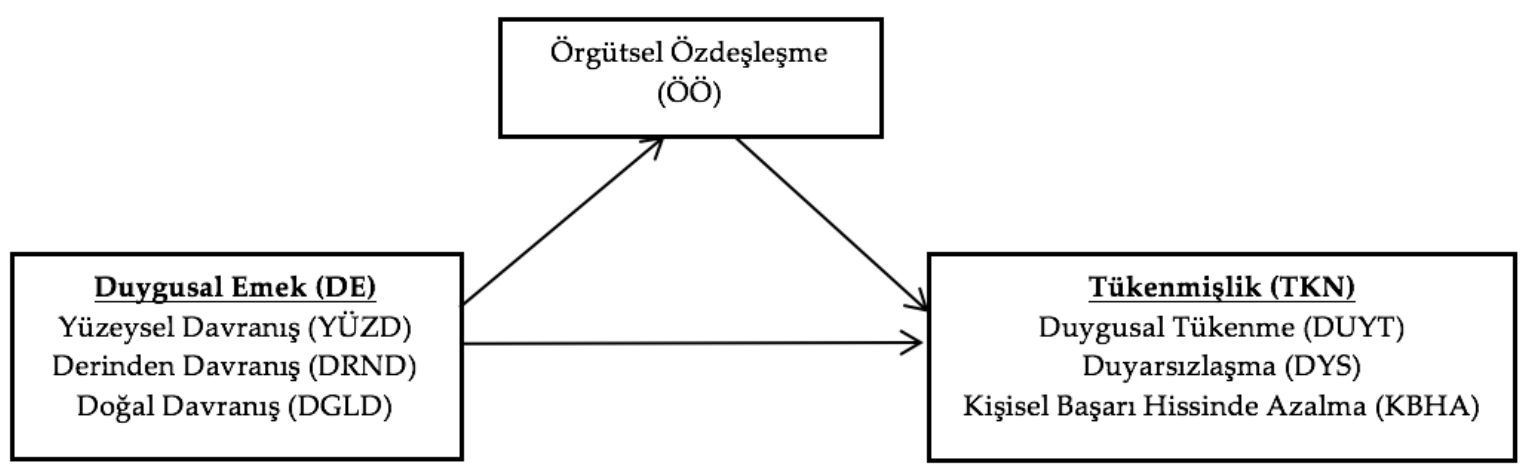

Şekil 1. Araştırmanın Kavramsal Modeli

DUYT: Duygusal tükenme, DYSZ: Duyarsızlaşma, KBHA: Kişisel başarı hissinde azalma, YÜZD: Yüzeysel davranış, DRND: Derinden davranış, DGLD: Doğal davranış, ÖÖ: Örgütsel özdeşleşme

\subsection{Araştırma Evren ve Örneklemi}

Araştırmada, İstanbul İl Sağlık Müdürlüğü'nden alınan izine bağlı kalarak İstanbul'daki özel hastanelerde çalışmakta olan personeller çalışmanın evrenini oluşturmaktadır.

Yazında belirtildiği üzere örneklem sayısının yeterliliği, istatistiksel olarak hesaplanmaktadır. 0,95 güven aralığı ve 0,05 örneklem hatasıyla temsil edilebilecek olan evren büyüklüğüne bağlı örneklem sayıları aşağıdaki Tablo 1'de ifade edilmiştir.

Tablo 1. Araştırmanın evrenine göre örneklem sayısı

\begin{tabular}{lcccccccccc}
\hline Evren Büyüklüğü & 100 & 150 & 250 & 500 & 1000 & 5000 & 10000 & 50000 & 100000 & 1000000 \\
\hline Örneklem Sayısı & 80 & 108 & 152 & 217 & 278 & 357 & 370 & 381 & 383 & 384 \\
\hline
\end{tabular}

Kaynak: Yazıcıŏ̆lu ve Erdoğan, 2014: 89. 


\section{S. Aksoy Kürü 13/1 (2021) 150-175}

Öte yandan, araştırmanın evreninden seçilecek örneklem sayısını belirlemek için evrenin sayısının net olarak belli olması durumunda örneklem sayısını hesaplamada kullanılacak eşitlik de aşağıda verilmiştir. Aşağıda verilen eşitliğe göre, İstanbul İl Sağlık Müdürlüğü Sağlık Araştırmaları Şube Müdürlügü̈ Özel Yataklı Sağlık Hizmetleri Şube Müdürlüğ̈’'ne bağlı kurum ve kuruluşlarda çalışan sağlık personellerinin tam sayısı bilinmediği için en üst değer olan 1000000 dahi olsa örneklem sayısının 348 olması yeterli kabul edilmektedir.

$\mathrm{n}=\mathrm{n}_{0} /\left(1+\mathrm{n}_{0} / \mathrm{N}\right), \mathrm{n}_{0}=\left(\mathrm{t}^{2} \mathrm{xs}\right) / \mathrm{d}^{2}$

Formüllerdeki ifadeler, N: evren büyüklüğ̈̈, n: örneklem büyüklüğü, t: güven düzeyine karş1lık gelen tablo z değeri $(0,05$ için $1,96,0,01$ için 2,58 ve 0,001 için 3,28$)$, s: evren için tahmin edilen standart sapma ve d: kabul sapma toleransinı ifade etmektedir (Bartlett vd. 2001).

$\mathrm{n}_{\mathrm{o}}=\left(1,96^{2} \times 0,5^{2}\right) / 0,05^{2}=384,16 \mathrm{n}=384,16 /(1+384,16 / 1000000)=348,042$

Tablo değerine ve formül değerine bağlı kalarak, hastanelere katılımcılara verilmek üzere toplamda 900 anket formu teslim edilmiştir. Doldurulduktan sonra geri alınan formlarının toplamı ise 817'dir. Analize alınabilecek anket formu sayısı ise $784^{\prime}$ tür. Elde edilen bu değer hem tablo hem de formül değerindeki eşik değerin oldukça üzerindedir. Bu durumda anket formlarının kullanılabilir olma oranı \%95,96'dır. Bu oran, Balcı'nın (2004) da ifade ettiği gibi istatistiksel olarak anlamlı bir yargıya ulaşmak için gerekli olan \%80 değerinin oldukça üstündedir.

Araştırma için geleneksel yöntemlere kıyasla genel kabul gören ve nispeten daha iyi sonuçlar veren, öncelikle belli bir kuramsal çerçeveye dayandırılarak gözlemlenen veya gözlemlenemeyen değişkenler arasındaki doğrudan veya dolaylı etkileri yalnızca tek bir model üzerinde inceleyerek test edebilen bir istatistik yöntemi olan yapısal eşitlik modellemesi (YEM) tercih edilmiştir (Byrne, 2001; Bayram, 2016; Eray-Çelik ve Yılmaz, 2016). Kurulan YEM modelinin analiz edilebilmesi amacıyla da güvenilir ve güçlü çözüm olanakları sunan AMOS yazılımı (Meydan ve Şeşen, 2015) kullanılmıştır.

\subsection{Veri Toplama Araçları}

Araştırmanın verisi, araştırmacılar tarafından daha önceden geçerliliği ve güvenirliliği test edilmiş olan ölçekler yardımıyla toplanmıştır. Veri toplama aracı olarak örneklemi oluşturan sağlık personellerine verilen anket formlarındaki ölçekler "Duygusal Emek Ölçeği”" (Diefendorff vd. (2005), "Örgütsel Özdeşleşme Ölçeği” (Mael ve Ashforth; 1992) ve "Tükenmişlik Ölçeği" (Maslach ve Jackson, 1981) olmak üzere üç tanedir. Tüm ölçeklerde birden fazla ifade (madde) kullanılmıştır. Katılımcıların bu ifadelere birden beşe kadar bir değer işaretlemesi için 5'li Likert tipi eşit aralıklı ölçekleme (1: Kesinlikle Katılmıyorum, 2: Katılmıyorum, 3: Kararsızım, 4: Katılıyorum ve 5: Kesinlikle Katılıyorum) kullanılmıştır. Kullanılan ölçeklere ilişkin tanımlayıcı bilgiler ve elde edilen bulgulara aşağıda yer verilmiştir.

\subsubsection{Duygusal Emek Ölçeği}

Duygusal emek ölçeği, Diefendorff vd. (2005) tarafından geliştirilen ve Türkçe uyarlaması Basım ve Begenirbaş (2012) tarafından yapılmış olan, yüzeysel davranış (YÜZD) alt boyutu, "Hastalarla göstermem gereken duyguları hissedebilmek için elimden geleni yaparım.", derinden davranış (DRND) alt boyutu, "Hastalara gösterdiğim duygular kendiliğinden ortaya çıkar." ve doğal davranış (DGLD) alt boyutu, "Hastalarla ilgilenirken iyi hissediyormuşum gibi görünmeye çalışırım." gibi benzeri ifadelerin yer aldığı toplam 14 ifadeli ve üç alt boyutlu bir ölçektir. On dört ifadeden oluşan orijinal ölçekte Cronbach Alfa Güvenirlik Katsayıları $(\alpha)$, yüzeysel davranış: 0,920, derinden davranış: 0,850 ve doğal davranış: 0,830'dur.

\subsection{2. Örgütsel Özdeşleşme Ölçeği}

Örgütsel özdeşleşme ölçeği, Mael ve Ashforth (1992: 110) tarafından geliştirilen ve Türkçe uyarlaması Tak ve Aydemir (2004) tarafından yapılmış olan, "Eğer, medyada çalıştığım hastane hakkında olumsuz yönde eleştirel bir haber çıkmışsa (çıkarsa) bundan rahatsızlık hisseder; utanç duyarım." ve "Çalıştığım hastaneden bahsederken; "onlar" yerine "biz" ifadesini kullanırım." gibi benzeri ifadelerin yer aldığı toplam altı ifadeli ve tek boyutlu bir ölçektir. Orijinal ölçekte Cronbach Alfa Güvenirlik Katsayısı $(\alpha)$, 0,780'dır.

\subsubsection{Tükenmişlik Ölçeği}

Tükenmişlik ölçeği, Maslach ve Jackson (1981) tarafından geliştirilen ve sağlık çalışanlarına yönelik Türkçe uyarlaması Ergin (1992) tarafından yapılmış olan, kişisel başarı hissinde azalma (KBHA) alt boyutu, 
"Yaptığım iş sayesinde hastalarımın yaşamına katkıda bulunduğuma inanıyorum.", duygusal tükenme (DUYT) alt boyutu, "Bütün gün hastalarla çalışmak benim için çok yıpratıcıdır." ve duyarsızlaşma (DYSZ) alt boyutu, "Hastalara ne olduğu umurumda değildir." benzeri ifadelerin yer aldığ1 toplam 22 ifadeli ve üç alt boyutlu bir ölçektir. Orijinal ölçekte Cronbach Alfa Güvenirlik Katsayısı $(\alpha)$ kişisel başarı hissinde azalma: 0,710, duygusal tükenme: 0,600 ve duyarsızlaşma: 0,800 iken Ergin'in ülkemizdeki çalışmasında ise; kişisel başarı hissinde azalma: 0,710, duygusal tükenme: 0,900 ve duyarsızlaşma: 0,790'dır.

\subsection{Araştırmada Verilerin Toplanması ve Analizi}

Araştırma verisi, araştırmacı tarafından İstanbul İl Sağlık Müdürlüğü'nden alınan izine bağlı kalarak İstanbul'daki özel hastanelerde çalışmakta olan personellerden anket formu yardımıyla toplanmıştır. Çalışma 2016 yılının mayıs ayı itibariyle başlatılmış olup 2017 yılının Mart ayında tamamlanmıştır.

Veri analizi için istatistik paket programları olan SPSS ve YEM (AMOS) kullanılmıştır. Betimleyici istatistikler, korelasyon analiz(leri), geçerlilik ve güvenirlik testleri ve keşfedici faktör analizleri için SPSS paket programı kullanılmıştır. Doğrulayıcı faktör analizleri, path analizleri ve aracılık etkisi analizleri için de YEM (AMOS) paket programı kullanılmıştır.

\subsection{Araştırmanın Etiği}

Araştırmaya başlamadan önce araştırmacı tarafından İstanbul İl Sağlık Müdürlüğü ile görüşülerek Doğuş Üniversitesi Meslek Yüksekokulu İnsan Kaynakları Yönetimi Programı arasında karşılıklı bir protokol oluşturularak İstanbul İl Sağlık Müdürlüğü Sağlık Araştırmaları Şube Müdürlüğü Özel Yataklı Sağlık Hizmetleri Şube Müdürlügü̈ne bağlı kurum ve kuruluşlarda çalışan sağlık personelleri üzerinde çalışmayı yürütmek üzere gerekli izinler alınmıştır. 30/12/2015 tarihli iki sene geçerliliği olan ilgili protokolle araştırma yapılacak olan özel hastanelere başvuru yapılarak katılımcılardan sözlü onam alınmıştır.

\subsection{Araştırmanın Sınırlılıkları}

Araştırma; nicel bir çalışma olup, kesitsel ve tanımlayıcı niteliktedir. Araştırmanın kesitsel olması nedeniyle ve araştırmaya dahil edilen değişkenlere verilen cevapların zaman içinde değişebileceği varsayımıyla araştırma sonunda elde edilen bulgular yalnızca araştırmanın uygulandığı zaman aralığıyla sınırlı kalmaktadır. Bunun yanı sıra, araştırma sonucu erişilen bulgular, verilerin toplanmasında yönelinmiş olunan örnekleme göre değişebilmektedir. Bu nedenle farklı örneklemler üzerinde de araştırmanın kavramsal modelinin test edilmesi gerekebilmektedir. Araştırmanın bir diğer kısıtı da yalnızca özel yataklı hastane hasta personelleri üzerinde ve yalnızca tek bir şehirde yapılmış olmasıdır.

\section{BULGULAR}

\subsection{Katılımcılara Ait Tanımlayıcı-Betimleyici Analiz Sonuçları}

Araştırmada, İstanbul İl Sağlık Müdürlüğü Sağlık Araştırmaları Şube Müdürlüğü Özel Yataklı Sağlık Hizmetleri Şube Müdürlüğü'ne bağlı kurum ve kuruluşlarda çalışan sağlık personellerinin yer aldığ örneklemin ( $\mathrm{n}=784)$ demografik özelliklerine ilişkin sonuçlara Tablo 2'de yer verilmiştir.

Tablo 2. Örneklemi Oluşturan Katılımcıların Demografik Özellikleri (n= 784)

\begin{tabular}{lccc}
\hline \multirow{2}{*}{ Değişken } & $\begin{array}{c}\text { Değişkenin } \\
\text { Alt Kategorileri }\end{array}$ & Frekans (n) & Yüzde (\%) \\
\hline \multirow{2}{*}{ Cinsiyet } & Kadin & 380 & 48,5 \\
\hline \multirow{2}{*}{ Medeni Hal } & Erkek & 404 & 51,5 \\
\hline \multirow{3}{*}{ Yaş } & Evli & 332 & 41,1 \\
& Bekar & 462 & 58,9 \\
\hline \multirow{2}{*}{ Eğitim } & $18-29$ yaş & 429 & 54,7 \\
& $30-39$ yaş & 237 & 30,2 \\
& $40-49$ yaş & 88 & 11,2 \\
& 50 yaş ve üzeri & 30 & 3,8 \\
\hline & Lise & 399 & 50,9 \\
& Üniversite & 266 & 33,93
\end{tabular}




\begin{tabular}{|c|c|c|c|}
\hline & Doktora & 87 & 11,10 \\
\hline \multirow{4}{*}{ Meslek } & Doktor & 87 & 11,10 \\
\hline & Hemşire-Ebe & 391 & 49,87 \\
\hline & Tibbi Sekreter & 193 & 24,62 \\
\hline & Diğer Sağlık Çalışanları & 113 & 14,41 \\
\hline \multirow{3}{*}{ Birlikte Çalışılan Personel Sayısı } & $1-10$ personel & 338 & 43,1 \\
\hline & 11- 25 personel & 287 & 36,6 \\
\hline & 26 ve üzeri personel & 159 & 20,3 \\
\hline \multirow{6}{*}{$\begin{array}{l}\text { Şu an Çalışılan Hastanedeki } \\
\text { Toplam Hizmet Süresi }\end{array}$} & 1 yıldan az & 212 & 27,0 \\
\hline & $1-5$ y1l & 366 & 46,7 \\
\hline & 6-10 yıl & 135 & 17,2 \\
\hline & $11-15$ yil & 36 & 4,6 \\
\hline & $16-20$ y1l & 22 & 2,8 \\
\hline & 21 yıl ve üzeri & 13 & 1,7 \\
\hline \multirow{6}{*}{ Sektördeki Toplam Hizmet Süresi } & $1-5$ y1l & 348 & 44,4 \\
\hline & 6-10 yıl & 265 & 33,8 \\
\hline & $11-15$ yil & 85 & 10,8 \\
\hline & $16-20$ yil & 45 & 5,7 \\
\hline & 21 yıl ve üzeri & 41 & 5,2 \\
\hline & Toplam & 784 & 100 \\
\hline
\end{tabular}

Tablo 2'ye göre, araştırmaya dahil olan katılımcıların \%48,5'i (n=380) kadın, \%51,5'i (n=404) erkektir. 784 katılımcının medeni durumunun çoğunluğu ise $\% 58,9^{\prime} u(n=462)$ bekar olup, katılımcıların $\% 54,7^{\prime}$ sinin yaş aralığı, 18-29 yaş aralığındadır, yaş ortalaması 31,46, standart sapma ise 8, 416'dır. 784 katılımcının \%50,9'u $(n=399)$ lise mezunudur. Katılımcıların birlikte çalıştığı personel sayısı ise, 1-10 personel aralığında olup; toplam katılımcıların \%43,1'ini temsil etmektedir. Şu an çalışılan hastanedeki toplam hizmet süresin en fazla olduğu aralık; 1-5 yıl (n=366), ortalama çalışma süresi 2,16 yıl ve standart sapma 1,060' dır. Sağlık sektöründeki toplam hizmet süresi ise mevcut hastanedeki çalışma süresiyle benzer şekilde 1-5 yıldır ( $n=348)$, ortalama süre 1,93 yil ve standart sapma $1,118^{\prime}$ dir.

\section{2. Ölçeklere İlişkin Güvenilirlik, Keşfedici ve Doğrulayıcı Faktör Analizi Sonuçları}

Araştırma dahilinde toplanan nicel veriler için uç değerler temizlenmiştir. Ayrıca, basıklık ve çarpıklık değerleri de kontrol edilmiş ve normallik varsayımı incelenmiştir. Analiz için uygun hale getirilen veriler için öncelikle geçerlik ve güvenirlik analizleri yapılmış olup; araştırma kapsamında kullanılmış olan ölçeklerin yapı geçerliklerini tespit edebilmek amacıyla SPSS programıyla keşfedici faktör analizi (KFA) (Büyüköztürk, vd. 2012) yapılmıştır. Anket formunda yer alan ifadeler için yapılan keşfedici faktör analizi sonuçlarına Tablo 3, Tablo 4 ve Tablo 5 'te yer verilmiştir.

\subsubsection{Duygusal Emek Ölçeğinin Güvenilirlik, Keşfedici ve Doğrulayıcı Faktör Analizi Sonuçları}

Duygusal emek ölçeği için bu araştırma kapsamında Bartlett testi sonucunun $((3966,276) / 41))$ anlamlı olarak bulgulanması ve Kaiser-Meyer-Olkin (KMO) katsayısı 0,844 olarak hesaplanması sonucunda veri matrisi faktör analizi için uygundur denilmektedir. Araştırmanın veri setiyle yapılan keşfedici faktör analizi esnasında ölçekten hiçbir madde analiz dışına alınmamıştır. Ölçek ifadelerinin faktör yükleri; yüzeysel davranış alt boyutu için 0,591-0,816, derinden davranış alt boyutu için 0,681-0,825 ve doğal davranış alt boyutu için ise 0,746-0,819 arasında dağılım göstermiştir. Ölçeğin üç faktörlü olduğu görülmüş olup; elde edilen üç faktörlü yapı yüzeysel davranış: \%26,122, derinden davranış: \%18,702 ve doğal davranış: \%14,769) yap1 toplam varyansın \%59,593'ünü açıklamaktadır. Orijinal ölçekte Cronbach Alfa Güvenirlik Katsayıları yüzeysel davranış: 0,920, derinden davranış: 0,850 ve doğal davranış: 0,830 iken araştırmamızda ise yüzeysel davranış: 0,845, derinden davranış: 0,802 ve doğal davranış: 0,759 ; ölçeğin geneli ise 0,788 olarak bulunmuştur (Bknz.: Tablo 3). 
Tablo 3. Duygusal Emek Ölçeğinin Güvenilirlik ve Keşfedici Analizi Sonuçları

Ölçek maddeleri

Boyutlara İlişkin Keşfedici Faktör

Analizi Faktör Yükleri

\begin{tabular}{|c|c|c|c|c|}
\hline Duygusal Emek (DE) & & YÜZD & DRND & DGLD \\
\hline YÜZD5 & & 0,816 & - & - \\
\hline YÜZD1 & & 0,774 & - & - \\
\hline YÜZD3 & & 0,727 & - & - \\
\hline YÜZD2 & & 0,697 & - & - \\
\hline YÜZD7 & & 0,696 & - & - \\
\hline YÜZD6 & & 0,692 & - & - \\
\hline YÜZD4 & & 0,591 & - & - \\
\hline DRND2 & & - & 0,825 & - \\
\hline DRND3 & & - & 0,805 & - \\
\hline DRND4 & & - & 0,757 & - \\
\hline DRND1 & & - & 0,681 & - \\
\hline DGLD3 & & - & - & 0,819 \\
\hline DGLD2 & & - & - & 0,811 \\
\hline \multirow[t]{8}{*}{ DGLD1 } & & - & - & 0,746 \\
\hline & Alt Boyutlar Cronbach Alfa $(\alpha)$ & 0,845 & 0,802 & 0,759 \\
\hline & Ölçeğin Genel Cronbach Alfa $(\alpha)$ & & 0,788 & \\
\hline & Alt Boyutlar Açıklanan Varyans & $\% 26,122$ & $\% 18,702$ & $\% 14,769$ \\
\hline & Açıklanan Toplam Varyans & & $\% 59,593$ & \\
\hline & KMO & & 0,844 & \\
\hline & Alt Boyutlar Ölçek Ortalaması & 2,82 & 3,51 & 3,69 \\
\hline & Ölçeğin Genel Ortalaması & & 3,34 & \\
\hline
\end{tabular}

Araştırmada kullanılan veri setiyle yapılan doğrulayıcı faktör analiziyle (DFA) elde edilen üç boyutlu faktör yapısının kabul edilebilir uyum değerlerine sahip olduğu görülmüştür $\left(\chi^{2}=239,152, s d=68, \chi^{2} / \mathrm{sd}=3,517\right.$, $\mathrm{p}=0,000, \mathrm{CFI}=0,956, \mathrm{GFI}=0,959, \mathrm{NFI}=0,940, \mathrm{IFI}=0,956, \mathrm{RMR}=0,082$, RMSEA=0,057, AGFI=0,937).

\subsection{3. Örgütsel Özdeşleşme Ölçeğinin Güvenilirlik, Keşfedici ve Doğrulayıcı Faktör Analizi Sonuçları}

Örgütsel özdeşleşme ölçeği için bu araştırma kapsamında ölçeğin, Bartlett testi sonucunun $((1269,815) / 78))$ anlamlı olarak bulgulanması ve Kaiser-Meyer-Olkin (KMO) katsayısı 0,826 olarak hesaplanması esnasında veri matrisi faktör analizi için uygundur denilmektedir. Araştırmanın veri setiyle yapılan keşfedici faktör analizi sonucunda ölçekten hiçbir madde analiz dışına alınmamıştır. Ölçek ifadelerinin faktör yükleri; 0,692 ile 0,816 arasında dağılım göstermiştir. Ölçeğin tek faktörlü olduğu görülmüş olup; elde edilen tek faktörlü yapı toplam varyansın \%50,186'sını açıklamaktadır. Orijinal ölçekte Cronbach Alfa Güvenirlik Katsayısı $(\alpha)$, 0,780 iken araştırmamızda ise 0,800 olarak bulunmuştur (Bknz.: Tablo 4).

Tablo 4. Örgütsel Özdeşleşme Ölçeğinin Güvenilirlik ve Keşfedici Analizi Sonuçları

\begin{tabular}{lc}
\hline Ölçek maddeleri & Keşfedici Faktör Analizi Faktör Yükleri \\
\hline Örgütsel Özdeşleşme (ÖÖ) & ÖÖ \\
\hline ÖÖ5 & 0,816 \\
ÖÖ4 & 0,774 \\
ÖÖ1 & 0,727 \\
ÖÖ2 & 0,697 \\
ÖÖ3 & 0,696 \\
ÖÖ6 & 0,692 \\
\hline \multicolumn{2}{r}{ KMO } \\
\hline Ölçeğin Genel Cronbach Alfa $(\boldsymbol{\alpha})$ & $\%, 800$ \\
\hline Açlklanan Toplam Varyans & 0,826 \\
\hline & Ölçeğin Genel Ortalamas1
\end{tabular}


Araştırmada kullanılan veri setiyle yapılan doğrulayıcı faktör analiziyle (DFA) elde edilen tek boyutlu faktör yapısının kabul edilebilir uyum değerlerine sahip olduğu görülmüştür $\left(\chi^{2}=19,786, s d=7, \chi^{2} / s d=2,827, p=0,006\right.$, CFI=0,990, GFI=0,992, NFI=0,984, IFI=0,990, RMR=0,027, RMSEA=0,048, AGFI=0,975).

\subsubsection{Tükenmişlik Ölçeğinin Güvenilirlik, Keşfedici ve Doğrulayıcı Faktör Analizi Sonuçları}

Tükenmişlik ölçeği için bu araştırma kapsamında ölçeğin Bartlett testi sonucunun $((5037,303) / 67))$ anlamlı olarak bulgulanması ve Kaiser-Meyer-Olkin (KMO) katsayısı 0,884 olarak hesaplanması sonucunda veri matrisi faktör analizi için uygundur denilmektedir. Araştırmanın veri setiyle yapılan keşfedici faktör analizi esnasında ölçekten DUYT8 ve DUYT9 ifadeleri analiz dışına alınmıştır. Ölçek ifadelerinin faktör yükleri; kişisel başarı hissinde azalma alt boyutu için 0,596-0,742, duygusal tükenme alt boyutu için 0,480-0,854 ve duyarsızlaşma alt boyutu için ise 0,596-0,742 arasında dağılım göstermiştir. Ölçeğin üç faktörlü olduğu görülmüş olup; elde edilen üç faktörlü (kişisel başarı hissinde azalma: $\% 16,077$ duygusal tükenme: \%18,192 ve duyarsızlaşma: \%14,293) yapı toplam varyansın \%48,563'ünü açıklamaktadır. Orijinal ölçekte Cronbach Alfa Güvenirlik Katsayısı $(\alpha)$ kişisel başarı hissinde azalma: 0,710, duygusal tükenme: 0,600 ve duyarsızlaşma: 0,800 iken Ergin'in ülkemizdeki çalışmasında ise; kişisel başarı hissinde azalma: 0,710, duygusal tükenme: 0,900 ve duyarsızlaşma: 0,790 iken araştırmamızda ise kişisel başarı hissinde azalma: 0,775 , duygusal tükenme: 0,846 ve duyarsızlaşma: 0,764; ölçeğin geneli ise 0,802 olarak bulunmuştur (Bknz.: Tablo 5).

Tablo 5. Tükenmişlik Ölçeğinin Güvenilirlik ve Keşfedici Analizi Sonuçları

\section{Ölçek maddeleri}

Boyutlara İlişkin Keşfedici Faktör Analizi Faktör Yükleri

\begin{tabular}{|c|c|c|c|c|}
\hline Tükenmişlik (TKN) & & DUYT & KBHA & DYSZ \\
\hline DUYT2 & & 0,854 & - & - \\
\hline DUYT1 & & 0,791 & - & - \\
\hline DUYT3 & & 0,788 & - & - \\
\hline DUYT5 & & 0,574 & - & - \\
\hline DUYT4 & & 0,535 & - & - \\
\hline DUYT7 & & 0,534 & - & - \\
\hline DUYT6 & & 0,480 & - & - \\
\hline KBHA5 & & - & 0,717 & - \\
\hline KBHA2 & & - & 0,714 & - \\
\hline KBHA7 & & - & 0,682 & - \\
\hline KBHA6 & & - & 0,672 & - \\
\hline КВНАЗ & & - & 0,646 & - \\
\hline KBHA1 & & - & 0,572 & - \\
\hline KBHA8 & & - & 0,481 & - \\
\hline KBHA4 & & - & 0,470 & - \\
\hline DYSZ5 & & - & - & 0,742 \\
\hline DYSZ1 & & - & - & 0,651 \\
\hline DYSZ2 & & - & - & 0,628 \\
\hline DYSZ3 & & - & - & 0,620 \\
\hline \multirow[t]{8}{*}{ DYSZ4 } & & - & - & 0,596 \\
\hline & Alt Boyutlar Cronbach Alfa $(\alpha)$ & 0,846 & 0,775 & 0,764 \\
\hline & Ölçeğin Genel Cronbach Alfa $(\alpha)$ & & 0,802 & \\
\hline & Alt Boyutlar Açıklanan Varyans & $\% 18,192$ & $\% 16,077$ & $\% 14,293$ \\
\hline & Açılanan Toplam Varyans & & $\% 48,563$ & \\
\hline & KMO & & 0,884 & \\
\hline & Alt Boyutlar Ölçek Ortalaması & 2,73 & 3,60 & 2,53 \\
\hline & Ölçeğin Genel Ortalaması & & 2,95 & \\
\hline
\end{tabular}

Araştırmada kullanılan veri setiyle yapılan doğrulayıcı faktör analiziyle (DFA) elde edilen üç boyutlu faktör yapısının kabul edilebilir uyum değerlerine sahip olduğu görülmüştür $\left(\chi^{2}=482,841, \mathrm{sd}=162, \chi^{2} / \mathrm{sd}=2,981\right.$, $\mathrm{p}=0,000, \mathrm{CFI}=0,934, \mathrm{GFI}=0,939, \mathrm{NFI}=0,905, \mathrm{IFI}=0,935, \mathrm{RMR}=0,064, \mathrm{RMSEA}=0,050, \mathrm{AGFI}=0,921$ ). 
Ölçeklere ilişkin güvenirlik alfa değerlerinin sosyal bilimlerde kabul görmüş olan 0 ile 1 arasında bir değer olan 0, 700 (Nunally, 1978, Altunışık, 2012) üzerinde olduğu bulgulanmıştır.

YEM'de yapılan DFA sırasında kullanılan ölçeklerin faktör yapıları incelenerek belli kriterler sınırında kabul edilebilir uyum değerleri oluşturup oluşturmadıklarına bakılmıştır. İfade edilen kriterlere bakıldığında; $\chi^{2} / \mathrm{sd}$ oranının iki birimin altında olması $(x \leq 2,0)$ elde edilen uyumun mükemmel olduğunu ifade ederken; üç ile beş birim arasında $(3,00 \leq x \leq 5,00)$ olmasıysa elde edilen uyumun kabul edilebilir uyumu ortaya koymaktadır (Kline, 2011). RMSEA değerinin 0,08 ile 0,05 arasında olması iyi uyum değerini, 0,05'in altında bir değerde olması ise çok iyi bir uyumu ifade etmektedir (Browne ve Cudeck, 1993). CFI, IFI ve NFI değerlerinin 0,951,00 arasında ve GFI değerinin 0,90 ile 0,95 arasında yer alması ise iyi bir uyumun elde edildiğini belirtmektedir (Bentler, 1980; Bentler ve Bonett, 1980; Baumgartner ve Homburg, 1996; Marsh vd., 2006).

\subsection{5. Ölçüm Modeline İlişkin Doğrulayıcı Faktör Analizi Sonuçları}

YEM'de yapılan DFA, araştırmaya dahil edilmiş olan değişkenlere ait tüm ölçekler için uygulanmıştır. Ölçeklerden tükenmişlik ölçeğinden DUYT8 ve DUYT9 ifadeleri silinmiştir. Hata kovaryansları; Şekil 2'de de belirtildiği gibi ÖÖ1 ile ÖÖ3, ÖÖ4 ile ÖÖ5, DRND1 ile DRND2, YÜZD1 ile YÜZD2 ve YÜZD3, YÜZD2 ile YÜZD4 ve YÜZD7, YÜZD4 ile YÜZD7, KBHA6 ile KBHA7, DUYT1 ile DUYT2 ve DUYT3, DUYT2 ile DUYT3, DUYT6 ile DUYT7, DYSZ2 ile DYSZ3, DYSZ3 ile DYSZ4 arasına eklenmiştir. Bu ekleme işleminin yapılmasının nedeni, eklenen maddelerin hata değerleri arasında ilişkili olmasıdır. Yapılan ölçüm modeli, kullanılan ölçeklerin veriyle iyi düzeyde uyum içinde olduğunu göstermektedir $\left(\chi^{2}=1639,512, \mathrm{sd}=704, \chi^{2} / \mathrm{sd}=\right.$ 2,329, $\mathrm{p}=0,000, \mathrm{CFI}=0,917, \mathrm{GFI}=0,903$, NFI $=0,864$, IFI=0,918, RMR=0,075, RMSEA=0,041, AGFI=0,887). Bunun yanı sıra, oluşturulan ölçüm modelinde yer alan gizil değişkenlerin birbirleriyle anlamlı ilişki içinde olduğu görülmüştür (Bknz.: Şekil 2).

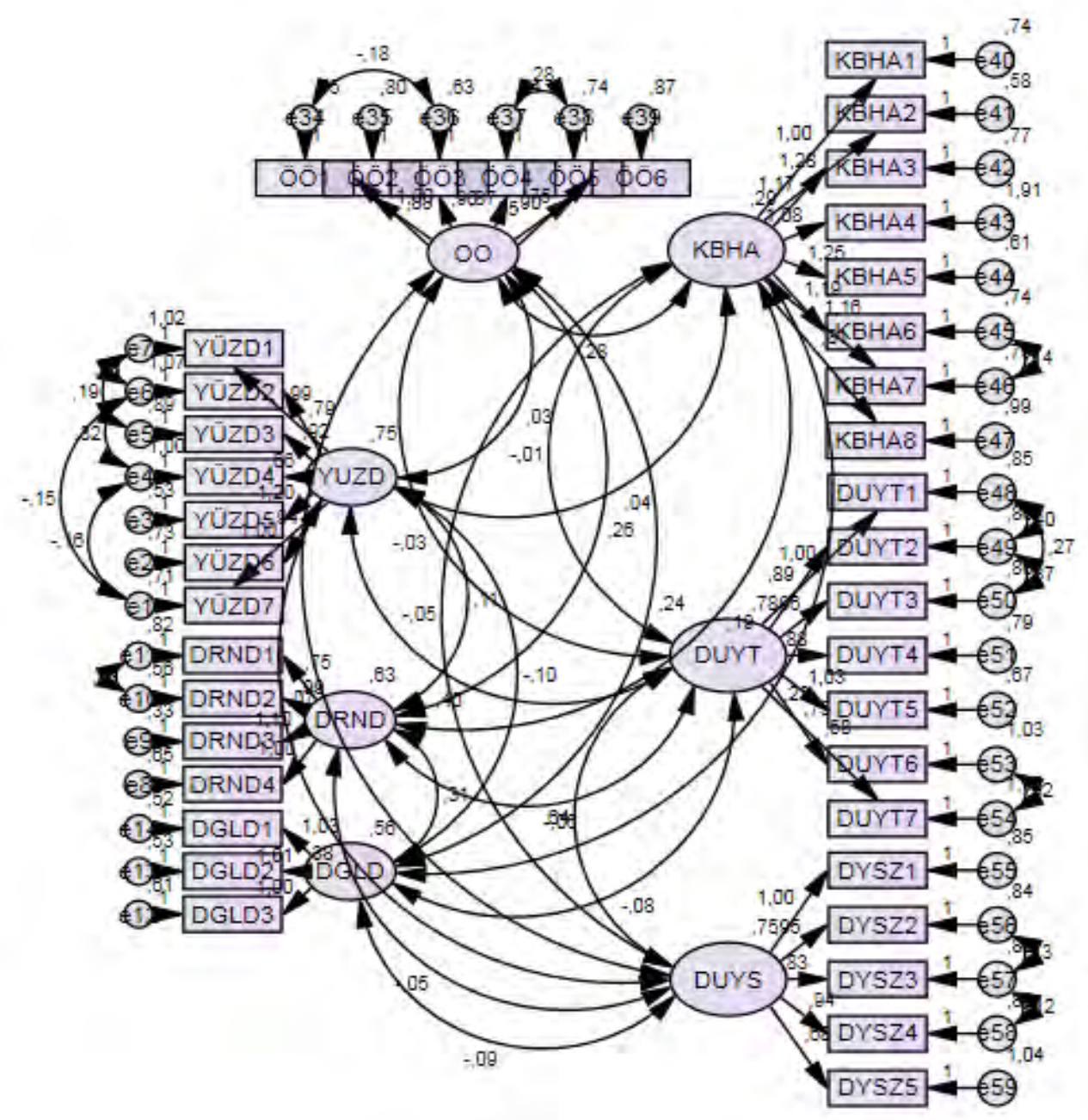

Şekil 2. Ölçüm Modeli İçin Yapılan Doğrulayıcı Faktör Analizi Sonuçları 


\subsection{Değişkenlere Ait Korelasyon Analizi Sonuçları}

Araştırmada yer alan katılımcıların anket formlarındaki ifadelere verdiği cevapların aritmetik ortalamalarının, minimum ve maksimum değerlerinin, standart sapmalarının ve değişkenler arasındaki ilişkinin seviyesini ve yönünü gösteren korelasyon katsayıları Tablo $6^{\prime}$ da yer almaktadır.

Tablo 6. Değişkenlere Ait Ortalama, Standart Sapma ve Korelasyon Katsayıları (n: 784)

\begin{tabular}{|c|c|c|c|c|c|c|c|c|c|c|c|}
\hline Değişkenler & Ort. & Min. & Max. & S. S. & DUYT & DYSZ & КВНA & YÜZD & DRND & DGLD & ÖÖ \\
\hline 1. DUYT & 2,73 & 2,46 & 3,28 & 0,841 & $0,846^{\alpha}$ & & & & & & \\
\hline 2. DYSZ & 2,53 & 2,31 & 2,78 & 0,871 & $0,685^{* *}$ & $0,764^{\alpha}$ & & & & & \\
\hline 3. KBHA & 3,60 & 3,43 & 3,76 & 0,704 & $-0,019$ & $-0,058$ & $0,775^{\alpha}$ & & & & \\
\hline 4. YÜZD & 2,82 & 2,82 & 3,34 & 0,888 & $0,437^{* *}$ & $0,367^{* *}$ & $0,112^{* *}$ & $845^{\alpha}$ & & & \\
\hline 5. DRND & 3,51 & 3,43 & 3,64 & 0,858 & $-0,016$ & $-0,015$ & $0,365^{* *}$ & $0,112^{* *}$ & $0,802^{\alpha}$ & & \\
\hline 6. DGLD & 3,69 & 3,63 & 3,76 & 0,874 & $-0,091^{*}$ & $-0,091^{*}$ & $0,427^{* *}$ & $0,365^{* *}$ & $0,402^{* *}$ & $0,759^{\alpha}$ & \\
\hline 7. ÖÖ & 3,48 & 3,19 & 3,73 & 0,801 & $-0,036^{*}$ & $0,090^{*}$ & $0,510^{* *}$ & $0,427^{* *}$ & $0,346^{* *}$ & $0,315^{* *}$ & $0,800^{\alpha}$ \\
\hline
\end{tabular}

"Korelasyon 0,01, "Korelasyon 0,05 düzeyinde anlamlıdır. (" $p<0,01),(" p<0,05)$, a: Değişsenin içsel güvenirlik katsayı (Cronbach Alfa). DUYT: Duygusal tükenme, DYSZ: Duyarsızlaşma, KBHA: Kişisel başarı hissinde azalma, YÜZD: Yüzeysel davranış, DRND: Derinden davranış, DGLD: Doğal davranış, ÖÖ: Örgütsel özdeşleşme

Tablo 6'ya göre; araştırmada yer alan değişkenler arasındaki ilişkilerin birçoğunun 0,01 ve 0,05 düzeyinde anlamlı olduğu görülmektedir. Araştırmadaki katılımcıların duygusal emek davranışının alt boyutlarından yüzeysel davranışın "Kararsızım (3)", derinden ve doğal davranışın ise "Katılıyorum (4)"; tükenmişliğin alt boyutlarından duygusal tükenmenin ve duyarsızlaşmanın "Kararsızım (3)", kişisel başarı hissinde azalmanın "Katılıyorum (4)"; ve örgütsel özdeşleşmelerinin "Katıllyorum (4)" düzeyinde olduğu görülmektedir. Korelasyon tablosundaki ilişkilere bakıldığında ise, duygusal emek değişkenin alt boyutlarından yüzeysel davranışın genel ortalaması, tükenmişliğin duygusal tükenme, duyarsızlaşma ve kişisel başarı hissinde azalma alt boyutlarıyla; derinden davranış ve doğal davranışın ise kişisel başarı hissinde azalma alt boyutuyla; örgütsel özdeşleşmenin kişisel başarı hissinde azalma, yüzeysel, derinden ve doğal davranışla 0,01 düzeyinde pozitif korelasyon içinde olduğu anlaşılmaktadır. Ayrıca, duygusal emek değişkenin alt boyutlarından doğal davranışın genel ortalaması tükenmişliğin duygusal tükenme ve duyarsızlaşma alt boyutlarıla 0,05 düzeyinde negatif korelasyon içindedir. Örgütsel özdeşleşmenin genel ortalaması tükenmişliğin duyarsızlaşma alt boyutuyla 0,05 düzeyinde pozitif korelasyon içindedir.

\section{4. Önerilen Modele İlişkin Hipotezlerin Yapısal Eşitlik Modeli İle Test Edilmesi}

Araştırmaya konu olan özel hastanelerde çalışan personellerin duygusal emek davranışı ve tükenmişlik arasındaki ilişki: örgütsel özdeşleşmenin aracılık etkisini test edebilmek amacıyla kavramsal araştırma modeli kurulmuştur. Model, YEM'de Baron ve Kenny (1986) yaklaşımıyla test edilmiştir. Yaklaşıma göre değişkenler arasındaki ilişkiler için ayrı ayrı yol (path) analizleri yapılmıştır. Öncelikle, bağımsız değişken olan duygusal emek davranışının (üç alt boyutu) bağımlı değişken olan tükenmişlik (üç alt boyutu) üzerindeki etkisinin varlığı test edilmiştir. Oluşturulan ilk regresyon yolu olan duygusal emek davranışının yüzeysel davranış alt boyutunun (YÜZD $\rightarrow$ KBHA: Standardize $\beta=0,064$, Standart hata $=0,027, p=0,018$ ), (YÜZD $\rightarrow$ DUYT: Standardize $\beta=0,307$, Standart hata $=0,062, p=0,000)$, (YÜZD $\rightarrow$ DYSZ: Standardize $\beta=0,692$, Standart hata $=0,059, p=0,000$ ) anlamlı olduğu görülmektedir. Elde edilen bu bulgulara bağlı kalarak $\mathrm{H}_{1}, \mathrm{H}_{2}$ ve $\mathrm{H}_{3}$ hipotezlerinin desteklendiği anlaşılmaktadır.

Duygusal emek davranışının derinden davranış alt boyutunun (DRND $\rightarrow$ KBHA: Standardize $\beta=0,120$, Standart hata $=0,038, p=0,001$ ), (DRND $\rightarrow$ DUYT: Standardize $\beta=-0,463$, Standart hata $=0,072, p=0,000$ ), (DRND $\rightarrow$ DYSZ: Standardize $\beta=-0,356$, Standart hata $=0,066, p=0,000$ ) anlamlı olduğu görülmektedir. Elde edilen bu bulgulara bağlı kalarak $\mathrm{H}_{4}, \mathrm{H}_{5}$ ve $\mathrm{H}_{6}$ hipotezlerinin desteklendiği anlaşılmaktadır.

Duygusal emek davranışının doğal davranış alt boyutunun (DGLD $\rightarrow$ KBHA: Standardize $\beta=0,355$, Standart hata $=0,048, p=0,001$ ), (DGLD $\rightarrow$ DUYT: Standardize $\beta=0,283$, Standart hata $=0,075, p=0,000$ ), (DGLD $\rightarrow$ DYSZ: Standardize $\beta=0,184$, Standart hata=0,069, $\mathrm{p}=0,000$ ) anlamlı olduğu görülmektedir. İlk altı hipotezde olduğu gibi benzer şekilde elde edilen bu bulgulara bağlı kalarak $\mathrm{H}_{7}, \mathrm{H}_{8}$ ve $\mathrm{H}_{9}$ hipotezlerinin desteklendiği anlaşılmaktadır. 
Ayrıca, kurulan regresyon yolu için DFA sonuçları da $\left(\chi^{2}=1542,273, \mathrm{sd}=504, \chi 2 / \mathrm{sd}=3,060, \mathrm{p}=0,000, \mathrm{CFI}=0,891\right.$, GFI=0,896, NFI=0,847, IFI=0,892, RMR=0,103, RMSEA=0,051, AGFI=0,877) bunu destekler niteliktedir.

İlk adımın yerine getirilmesiyle aracılık testi için gereken ikinci adımda ise, bağımsız değişken olan duygusal emek davranışının aracı değişken olan örgütsel özdeşleşme üzerindeki etkisinin varlığı incelenmiştir. İkinci adım için yapılmış olan analiz neticesinde değişkenler arasında yalnızca yüzeysel davranışın örgütsel özdeşleşme ile anlamlı bir ilişkinin olmadığ (YÜZD $\rightarrow$ ÖÖ: Standardize $\beta=0,033$, Standart hata=0,040, p=0,406) görülmüştür. $\mathrm{Bu}$ durumda elde edilen bu sonuca bağlı kalarak $\mathrm{H}_{10}$ : Özel hastanelerde çalışan sağlık personellerinin yüzeysel davranışının örgütsel özdeşleşmeye etkisi vardır hipotezi desteklenmemektedir. Duygusal emeğin diğer iki alt boyut olan derinden davranış (DRND $\rightarrow$ ÖÖ: Standardize $\beta=0,267$, Standart hata $=0,057, p=0,000$ ) ile doğal davranışın örgütsel özdeşleşmeyle anlamlı bir ilişki (DGLD $\rightarrow$ ÖÖ: Standardize $\beta=0,266$, Standart hata $=0,061, p=0,000$ ) içerisinde olduğu bulgulanmıştır. Elde edilen bu bulgulara bağlı kalarak $\mathrm{H}_{11}$ ve $\mathrm{H}_{12}$ hipotezlerinin desteklendiği anlaşılmaktadır. Duygusal emeğin örgütsel özdeşleşmeyle olan ilişkisini ele alan yol analizi için elde edilen DFA sonuçlarıyla da $\left(\chi^{2}=410,897, \mathrm{sd}=157, \chi^{2} / \mathrm{sd}=2,6179, \mathrm{p}=0,000\right.$, $\mathrm{CFI}=0,952, \mathrm{GFI}=0,949, \mathrm{NFI}=0,926$, IFI=0,953, RMR=0,072, RMSEA=0,045, AGFI=0,932) bu ilişki doğrulanmıştır.

Üçüncü adımda ise aracı değişken olan örgütsel özdeşleşmenin bağımlı değişken olan tükenmişlik (üç alt boyutu) üzerindeki etkisine bakılmak amacıyla yeni bir regresyon modeli oluşturulmuştur. Yapılan analiz sonucunda kurulan bu ilişkilerden yalnızca örgütsel özdeşleşmenin duygusal tükenme ile anlamlı bir ilişki içinde olduğu (ÖÖ $\rightarrow$ DUYT: Standardize $\beta=-0,088$, Standart hata $=0,04, p=0,000$ ) görülmüştür. Benzer şekilde, örgütsel özdeşleşmenin tükenmişliğin diğer iki alt boyut olan kişisel başarı hissinde azalma (ÖÖ $\rightarrow$ KBHA: Standardize $\beta=0,503$, Standart hata $=0,051, p=0,000$ ) ile duyarsızlaşmayla da anlamlı bir ilişki (ÖÖ $\rightarrow$ DYSZ: Standardize $\beta=0,115$, Standart hata $=0,058, p=0,047)$ içinde olduğu sonucu tespit edilmiştir. Elde edilen bu bulgulara bağlı kalarak $\mathrm{H}_{13}, \mathrm{H}_{14}$ ve $\mathrm{H}_{15}$ hipotezlerinin desteklendiği anlaşılmaktadır. Bunun yanı sıra, örgütsel özdeşleşmenin tükenmişlikle olan ilişkisini ele alan yol analizi için elde edilen DFA sonuçları da $\left(\chi^{2}=807,245\right.$, $\mathrm{sd}=285, \chi^{2} / \mathrm{sd}=2,832, \mathrm{p}=0,000, \mathrm{CFI}=0,921, \mathrm{GFI}=0,923, \mathrm{NFI}=0,983, \mathrm{IFI}=0,921$, RMR=0,069, RMSEA=0,048, AGFI $=0,905)$ bu tespiti destek şekildedir.

Değişkenler arasındaki aracılık etkisini test edilebilmek amacıyla gerekli ilk üç şart tam ve eksiksiz yerine getirilmiştir. Anlamlı olmayan yollar analizden çıkarılarak, dördüncü adım olan duygusal emek davranışı ile tükenmişlik arasındaki ilişkide, örgütsel özdeşleşmenin aracılık etkisinin olup olmadığını görebilmek maksadiyla yeni bir yol analizi modeli kurulmuştur. Kurulan ölçüm modelinin verilerle olan uyumunun iyi düzeyde elde edilmesinden sonra gizil değişkenler arasındaki kovaryanslar silinerek kuramsal çerçeveye uygun olacak şekilde tek yönlü yollar eklenerek analiz tamamlanmıştır. (Bknz.: Şekil 3). YEM'deki DFA değerlerinin de eldeki verilerle uyumlu olduğu tespit edilmiştir $\left(\chi^{2}=1254,336, s d=477, \chi^{2} / \mathrm{sd}=2,630, p=0,000\right.$, $\mathrm{CFI}=0,911, \mathrm{GFI}=0,908, \mathrm{NFI}=0,864, \mathrm{IFI}=0,911, \mathrm{RMR}=0,068, \mathrm{RMSEA}=0,046, \mathrm{AGFI}=0,892, \mathrm{SRMR}=0,051$ ). 


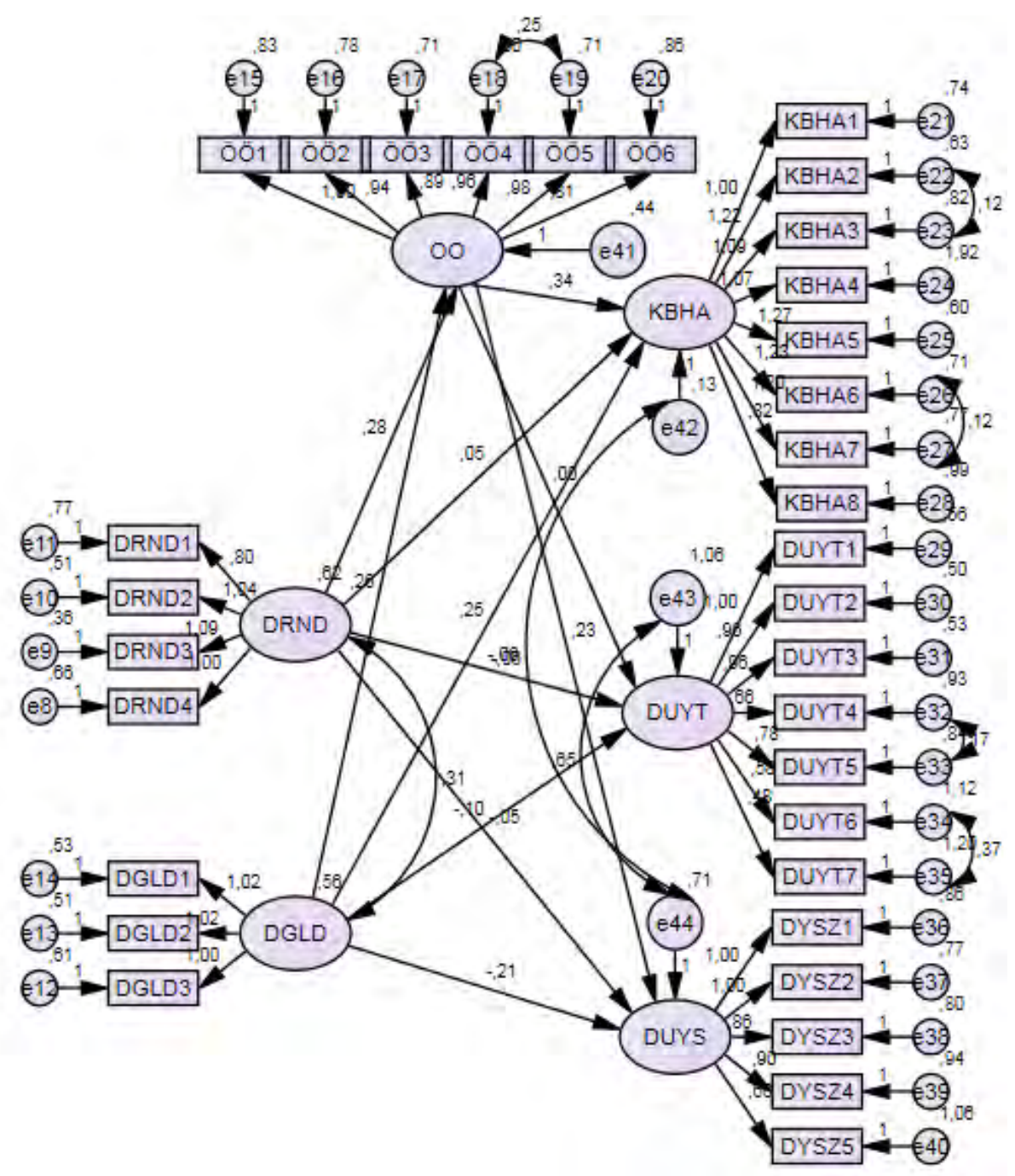

Şekil 3. Standardize Edilmiş Yol Katsayıları İle Yapılan Yapısal Eşitlik Modeli

Aracılık testi için takip edilen ilk üç adımdaki bulgulara bağlı kalarak $\mathrm{H}_{10}$ hipotezinin desteklenmemesi üzerine, YÜZD duygusal emek boyutu aracılık testi esnasında analiz dışına çıkarılmıştır. Şekil 3'te görünen bağımsız değişken olan duygusal emek davranışının bağımlı değişken olan tükenmişlik üzerindeki anlamlı etkisinin ilk durumdaki etkisi ve aracı değişken olan örgütsel özdeşleşmenin modele dahil edilmesi sonucundaki etkiler aşağıdaki tabloda (Bknz.: Tablo 7) belirtilmiştir.

Tablo 7. Aracılık Testi Sonuçları

\begin{tabular}{|c|c|c|}
\hline Yollar & Aracı Değişken Eklenmeden Önce & Aracı Değişken Eklendikten Sonra \\
\hline YÜZD $\rightarrow$ KBHA & Std. $\beta=0,064$, Std. hata $=0,027, p=0,018$ & \multirow{3}{*}{$\begin{array}{l}\text { YÜZD ve ÖÖ yolu çizilemediği için } \\
\text { YÜZD analiz dışına alınmıştır. }\end{array}$} \\
\hline YÜZD $\rightarrow$ DUYT & Std. $\beta=0,307$, Std. hata $=0,062, p=0,000$ & \\
\hline YÜZD $\rightarrow$ DYSZ & Std. $\beta=0,692$, Std. hata $=0,059, p=0,000$ & \\
\hline DRND $\rightarrow$ KBHA & Std. $\beta=0,120$, Std. hata $=0,038, p=0,001$ & Std. $\beta=0,046$, Std. hata $=0,033, p=0,165$ \\
\hline DRND $\rightarrow$ DUYT & Std. $\beta=-0,463$, Std. hata $=0,072, p=0,000$ & Std. $\beta=-0,062$, Std. hata $=0,070, p=0,396$ \\
\hline DRND $\rightarrow$ DYSZ & Std. $\beta=-0,356$, Std. hata $=0,066, p=0,000$ & Std. $\beta=-0,054$, Std. hata $=0,065, p=0,400$ \\
\hline DGLD $\rightarrow$ KBHA & Std. $\beta=0,355$, Std. hata $=0,048, p=0,000$ & Std. $\beta=0,249$, Std. hata $=0,040, p=0,000$ \\
\hline DGLD $\rightarrow$ DUYT & Std. $\beta=0,283$, Std. hata $=0,075, p=0,000$ & Std. $\beta=-0,098$, Std. hata $=0,079, p=0,213$ \\
\hline DGLD $\rightarrow$ DYSZ & Std. $\beta=0,184$, Std. hata $=0,069, p=0,007$ & Std. $\beta=-0,207$, Std. hata $=0,071, p=0,003$ \\
\hline
\end{tabular}

Gerek Şekil 2'deki gerek Tablo 7'deki değerlere bakıldığında örgütsel özdeşleşmenin aracılık etkisine ilişkin hipotezler için değerlendirme yapabilmek mümkündür. Duygusal emek davranışı ile tükenmişlik arasındaki ilişkiye aracı değişken rolündeki örgütsel özdeşleşmenin eklemesinin ardından; derinden davranışın kişisel başarı hissinde azalmaya etkisinde önemli bir düşüş olduğu $(\beta=0,120$ değerinden $\beta=0,046$ değerine) ve hatta 
ilişkinin istatistiksel anlamlılık düzeyinin $(\mathrm{p}=0,165)$ tamamen yitirildiği görülmektedir. Elde edilen bu bulgulara göre $\mathrm{H}_{19}$ : Özel hastanelerde çalışan sağlık personellerin derinden davranışının kişisel başarı hissinde azalmaya etkisinde örgütsel özdeşleşmenin aracılık rolü bulunmaktadır hipotezi örgütsel özdeşleşmenin tam aracılık rolünün varlığıyla desteklenmektedir. Derinden davranışın duygusal tükenmeye etkisinde örgütsel özdeşleşmenin modele dahil edilmesiyle başlangıçtaki etkinin çok daha düşük bir değere $(\beta=-0,463$ değerinden $\beta=-0,062$ değerine) ulaştı̆̆ görülmektedir; duyarsızlaşamaya etkisinde de benzer aracilık etkisi ( $\beta=-0,356$ değerinden $\beta=-0,054$ değerine) değişmiş olduğu görülmektedir. $\mathrm{Bu}$ durumda da $\mathrm{H}_{20}$ : Özel hastanelerde çalışan sağlık personellerinin derinden davranışının duygusal tükenmeye etkisinde örgütsel özdeşleşmenin aracilık rolü bulunmaktadır ve $\mathrm{H}_{21}$ : Özel hastanelerde çalışan sağlık personellerin derinden davranışının duyarsızlaşmaya etkisinde örgütsel özdeşleşmenin aracılık rolü bulunmaktadır hipotezleri örgütsel özdeşleşmenin tam aracılık rolünün varlığıyla desteklenmektedir.

Duygusal emek davranışı ile tükenmişlik arasındaki ilişkiye aracı değişken rolündeki örgütsel özdeşleşmenin eklemesinin ardandan; doğal davranışın kişisel başarı hissinde azalmaya etkisinde nispeten bir düşüş olduğu ( $\beta=0,355$ değerinden $\beta=0,249$ değerine) görülmektedir. Elde edilen bu bulgulara göre $\mathrm{H}_{22}$ : Özel hastanelerde çalışan sağlık personellerinin doğal davranışının kişisel başarı hissinde azalmaya etkisinde örgütsel özdeşleşmenin aracılık rolü bulunmaktadır hipotezi örgütsel özdeşleşmenin kısmi aracılık rolünün varlığıyla desteklenmektedir. Doğal davranışın duygusal tükenmeye etkisinde örgütsel özdeşleşmenin modele dahil edilmesiyle başlangıçtaki etkinin oldukça düşük bir değere ( $\beta=0,283$ değerinden $\beta=-0,098$ değerine) ulaştığ ve anlamlılık düzeyinin başlangıçtaki duruma kıyasla azaldığı görülmektedir bu durumda da $\mathrm{H}_{23}$ : Özel hastanelerde çalışan sağlık personellerinin doğal davranışının duygusal tükenmeye etkisinde örgütsel özdeşleşmenin aracılık rolü bulunmaktadır hipotezi kişisel başarı hissinde azalmada gerçekleşen durumla benzerdir ve örgütsel özdeşleşmenin tam aracılık rolünün varlığıyla desteklenmektedir.

Doğal davranışın duyarsızlaşamaya etkisinde ise örgütsel özdeşleşmenin modele dahil edilmesiyle önemli bir düşüş olduğu ( $\beta=0,184$ değerinden $\beta=-0,207$ değerine) görülmektedir. Elde edilen bu bulgulara göre $\mathrm{H}_{24}$ : Özel hastanelerde çalışan sağlık personellerinin doğal davranışının duyarsızlaşmaya etkisinde örgütsel özdeşleşmenin aracılık rolü bulunmaktadır hipotezi örgütsel özdeşleşmenin kısmi aracılık rolünün varlığıyla desteklenmektedir.

Bunların yanı sıra; örgütsel özdeşleşmenin tükenmişlik (duyarsızlaşma ve kişisel başarı hissinde azalma) üzerindeki anlamlı etkisinin devam ettiği tespit edilmiştir. Elde edilen bu sonuçlara göre bağımsız değişken olan duygusal emek ile modele dâhil edilen aracı değişken olan örgütsel özdeşleşmenin tam ve kısmi aracılık etkisi oluşturduğu rahatlıkla ifade edilebilmektedir. Bunun yanı sıra, aracılık etkisinin test edilebilmesi için oluşturulan regresyon modelinin uyum indeksleri de $\left(\chi^{2}=1254,336, \mathrm{sd}=477, \chi^{2} / \mathrm{sd}=2,630, \mathrm{p}=0,000, \mathrm{CFI}=0,911\right.$, GFI $=0,908, \mathrm{NFI}=0,864, \mathrm{IFI}=0,911$, RMR=0,068, RMSEA=0,046, AGFI=0,892, SRMR=0,051) ilgili modelin iyi uyum aralığında olduğunu belirtmekte ve değişkenin aracılık etkisi oluşturduğunu doğrular şekildedir.

\section{SONUÇ ve TARTIŞMA}

Araştırmada özel hastanelerde çalışan sağlık personellerinin duygusal emek davranışı ve tükenmişlik arasındaki ilişki: örgütsel özdeşleşmenin aracılık etkisini sorgulamak amaçlanmıştır. Bu temel motivasyondan hareketle öncelikle araştırmaya konu olan değişkenlerin durumu ve aralarındaki ilişki ele alınmıştır. Hizmet sektöründeki örgütlerde müşterilerle birebir iletişim ve ilişki kurma söz konusu olduğu için çalışandan mesleki bilgisini ve becerisini aktarmasının ötesinde duygularını da aktarması beklenmektedir (Kozak ve Güçlü, 2008). Duygusal emeğin hastane ortamındaki yansıması ise yoğun bir maneviyatı da içermektedir. Bu nedenle de duyguların aktarımındaki ve karşı tarafa hissettirilmesinde çeşitli nedenlerle farklılık oluşmaktadır. Çalışanların bedenleri ve yüz hareketleri yardımıyla duygularını ve hislerini yansıttıkları duygusal emeğin (Diefendorff vd., 2005), alt boyutlarından yüzeysel davranışın derinden davranış alt boyutuna (Ort.=3,51) ve doğal davranış alt boyutuna (Ort.=3,69) nazaran daha düşük seviyede (Ort.= 2,82) seyrettiği bulgulanmıştır. Sağlık personellerinin doğal davranış sergileyerek duygularını karşı tarafa aktarmayı tercih ettikleri gözlemlenmiştir. Elde edilen bu sonuçları, sağlık sektöründe çalışan personellerin mesleklerine ve mesleklerinin manevi değerine ve özelliklerine sıkı sıkıya bağlı oldukları anlaşılmaktadır. Ashforth ve Humphrey'in (1993) ifadesini doğrular nitelikteki bu sonuçla, insanların psikolojik birer canlı oldukları ve onlardan beklenen davranışları samimiyetle ve içtenlikle karşı tarafa doğal olarak aktarabildikleri 
söylenebilir. Nitekim, hastanelerdeki personelin sabrı ve anlayışı, öte yandan hoşgörüsüne ve içten gelen yardımsever davranışlarına hasta ve hasta yakınları birebir şahittir.

İstanbul İl Sağlık Müdürlüğü Sağlık Araştırmaları Şube Müdürlüğü Özel Yataklı Sağlık Hizmetleri Şube Müdürlüğü'ne bağlı özel yataklı hastanelerde çalışan 784 sağlık personelinin örgütleriyle yaşadıkları özdeşleşme ise oldukça yüksek (Ort.= 3,48) seyretmektedir. Elde edilen bu değere bağlı olarak, Ashforth ve meslektaşlarının da (2008) belirttiği gibi, araştırmaya konu olan özel hastanelerdeki personellerin örgütlerine yönelik yoğun bir sadakat içinde olduğu ve bu sayede de birlik ve bütünlük içinde olduklarının bir göstergesidir. Özel yataklı hastanelerde yapılan bu çalışmada elde edilen örgütsel özdeşleşme değerine göre, personellerin örgütlerini diğerlerine karşı temsil etme bilinci içinde oldukları da anlaşılmaktadır.

784 sağlık personelinin tükenmişlik durumlarına bakıldığında ise, bireyin birebir kendini değerlendirmesini ifade eden ve yaptığı değerlendirmeye göre kendini yetersiz hissederek suçlamaya yöneldiği boyut olan kişisel başarı hissinde azalma boyutunun (Maslach ve Goldberg, 1998), en yüksek değere sahip olduğu (Ort.: $3,60)$ görülmektedir. Bu değere bağlı olarak, bireyin kendisinden işle ilgili talep edilenleri yerine getirme konusunda eksiklik duyduğu inancı ve düşüncesi hakimdir demek mümkündür. Diğer iki alt boyutun ortalama değerlerinin hemen hemen birbirine yakın oldukları görülmektedir (Bknz.: Tablo 6).

Kavramlar arasındaki ilişki durumuna baktığımızda duygusal emeğin alt boyutlarından olan; çalışanın aslında tam olarak hissetmese de karşı tarafa varmış, hissediyormuş gibi yansıttığı duyguların aktarımını ifade eden yüzeysel davranışın (Chu ve Murrmann, 2006) tükenmişliğin duygusal tükenme alt boyutuyla daha fazla ilişkili olduğu görülmektedir (Maslach, vd., 2001). Yüzeysel davranış alt boyutunun etkileme durumlarına bakıldığında ise en az kişisel başarı hissinde azalmada etki oluşturduğu anlaşılmaktadır. Seçer ve Tinar'ın (2004) hemşireler üzerinde yürüttüğü çalışmasında da benzer bir sonuç elde edilmiştir. Kruml ve Geddes'in de (2000) sağlık sektöründe yaptığı çalışmanın bulgularıyla benzerlik gösteren bu sonuç, bireyin şahsi olarak çaba göstermediği ve emek harcamadığı aktarımdan dolayı herhangi bir üzüntü duymayacağı, örgütünün ondan istediklerini vererek işini icra ettiği için bireysel anlamda da bir yetersizliğe sevk olmayacağ 1 şeklinde yorumlanabilir. Oysa ki, idealizm kaybına uğramış olmayı temsil eden duyarsızlaşma alt boyutuna etkisi oldukça yüksek seyretmedir. Çalışanın kendini korumak amacıyla tampon bölge oluşturması olarak temsil edilen duyarsızlaşma (Maslach ve Goldberg, 1998), muhatap olduğu hizmet alıcılarla kendi duygularını istediği gibi aktaramamadan (yüzeysel davranış) etkilenmektedir. Öte yandan çalışanın duygusal kaynaklarının bitmeye yakın olduğunu ifade eden duygusal tükenme alt boyutuna etkisinin de olduğu görülmektedir. Bu bulgu da alandaki diğer araştırmacıların bulgularıyla paralellik göstermektedir (Grandey, 2003; Brotheridge ve Lee, 2003; Zammuner ve Gali, 2005; Chau, vd., 2009).

Derinlemesine davranışın etkileri ise duygusal tükenme üzerinde diğer iki alt boyuta nazaran daha fazla görülmektedir. Burada da kültürel değerlerin ve maneviyatın baskın gelerek geçmiş dönem tecrübeleri ve anıların akla gelmesi ve bu sayede bir duyguyu uyandırıp harekete geçirmenin yardımının ve yansımalarının olduğu ileri sürülebilir. Elde edilen bu sonuç, alandaki çalışmalardaki (Wharton, 1993; Jones, 1998; Kruml ve Geddes, 2000) bulgularla benzerlik göstermektedir. Güler yüzlü ve dostça davranarak icra edilen iş sayesinde duygusal tükenmede negatif bir etki oluşmaktadır (Grandey, 2000; Brotheridge ve Grandey, 2002; Öz, 2007; Chau, vd., 2009). Bu da istenen bir durumdur. Ayrıca belirtmek gerekir ki yüzeysel davranış sergileyen çalışanların, derinden davranış sergileyen çalışanlara kıyasla daha yüksek düzeyde tükenmişlik yaşadığı tespit edilmiştir (Bknz.: Tablo 6). Benzer nitelikte bir sonuç Değirmenci'nin (2010) hemşirelere üzerinde yaptığ1 çalışmasında da karşımıza çıkmaktadır.

Çalışanların sergileyeceği derinlemesine ve doğal davranışların olması halinde örgütsel özdeşleşme gibi istenen bir durumun oluşması beklenmektedir (Altın Gülova, vd., 2013). Araştırmanın bulgularında da bu beklenti doğrulanmıştır. Yüzeysel davranışın örgütsel özdeşleşme üzerinde anlamlı bir etkisini olmaması sebebiyle, yüzeysel davranış aracılık etki analizinden çıkarılmışır. Örgütsel özdeşleşmenin aracı değişken rolünün tespiti için analizin tekrar yapılmasıyla bulgularda farklılıklar oluşmuştur. Örgütsel özdeşleşmenin dahil edilmesiyle yüzeysel davranışın tükenmişlik üzerindeki etkisi bakılamamışır (Bknz.: Şekil 3). Bu durumu örgütsel özdeşleşmenin özelliği olan hem hal olup bütünlük içinde olabilmeyle ilişkilendirebilecekken; bu araştırmada bu durum kontrol edilememiştir. Nitekim, örgütün belirlediği kurallara ve prosedürlere bağlı kalarak duyguların davranışa dönüştürülmesi olan yüzeysel davranışın Mael ve Ashforth'un (1992) da belirttiği gibi bir olma veya bütünün parçası olmayı ifade eden örgütsel 


\section{S. Aksoy Kürü 13/1 (2021) 150-175}

özdeşleşmeyle etkileşim içine girerek duygusal tükenmeyi etkilediği düşünülebilirdi. Yüzeysel davranışın aracı değişken olan örgütsel özdeşleşme analize eklendikten sonraki durumu için başlangıçtaki anlamlı etkisine ilişkin herhangi bir değerlendirme yapılamamaktadır. Elde edilen bu sonuç, örgütsel özdeşleşmenin aracılık etkisini inceleyen nadir çalışmalardan biri olan Yılmaz'ın (2014) bulgularıyla da benzerlik göstermemektedir. Derinden davranışın kişisel başarı hissinde azalmaya olan etkisi örgütsel özdeşleşmenin birlikle analize alınmasıyla anlamlılığını tamamen yitirmiştir. Bu durumu, çalışanın iç dünyasında yaşanan çatışmalar ve duygu durumlarına odaklanan derinden davranışın bireyin kendini yetersiz hissetmesinde yaşadığı olumsuz durumu örgütüyle yaşadığı yüksek özdeşleşme sayesinde ortadan kaldırabileceği anlaşılmaktadır. Örgütsel özdeşleşmenin tam aracılık rolüyle, derinden davranışın kişisel başarı hissinde azalmaya olan etkisi anlamlılığını yitirerek ortadan kalkmıştır. Bireyin iç dünyasında olanları bir süzgeçten geçirerek dışa yansıttığı davranışları (derinden davranış), örgütüyle bütünlük içinde olması sayesinde avantaja çevirebilmektedir. Bu sayede de yaşadığı bu tükenmişlik durumunu yöneterek ortadan kaldırabilmektedir demek de mümkündür. Bir diğer etki olan doğal davranışın duyarsızlaşma üzerindeki etkisi, örgütsel özdeşleşmenin devreye girmesiyle büyük ölçüde azaldığı anlaşılmaktadır. Ashforth ve Humphrey'in deyimiyle (1993) samimi ve adeta birebir kendi duygu ve düşüncelerinin dışa vurulmasını ifade eden doğal davranışlar gösteren bir çalışanın örgütüyle yaşadığı özdeşleşme sayesinde duyarsızlaşma hissetmeyeceği sonucuna ulaşılmıştır. Kendini örgütün yegâne bir temsilcisi olarak kabul etme düşüncesiyle yani örgütsel özdeşleşme mantığıyla hareket eden bir çalışan hizmet sunduğu bireyleri değersiz görmeyerek onlara karşı duyarlı ve yapıcı duygularla yaklaşacaktır. Onların birer insan olduklarını ve daha da önemlisi örgütünü onun sergilediği davranışlarla değerlendiren bireyler olduğunu bilerek çaba sergileyecektir. Sergilenen samimi davranışlar ve örgütüyle yaşadığı özdeşleşmeyle birlikte işinden ve işinin gerektirdiklerinden uzaklaşmak yerine daha da yakınlaşma oluşacaktır. Kalıplaşmış davranış kalıplarına ve kurallara göre adeta bir robot gibi hareket etmek yerine; sıcak ve ilgili bir yaklaşım görülecektir. Kişiler arası boyut olan duyarsızlaşma (Maslach ve Goldberg, 1998), örgütün iş çıktılarının doğrudan sergilendiği noktadadır. İyi yönetilememesi halinde örgütü yıkıcı bir sona doğru götürebilmektedir (Polatçı, 2007). Örgütsel özdeşleşmenin başkalarının görüş ve düşüncelerinin dikkate alınarak hareket edilmesi gerektiği bilgisine bağlı olarak samimi davranış sergilenmesiyle duyarsızlaşmanın giderilmesi gerçekleşmektedir. Bu da özel sektörün ciddi bir rekabet içinde olduğu çalışma dünyasında fazlasıyla istenen bir durumdur.

Yöneticilere yönelik önerilerin en başında sağlık sektöründe yapılan işin öneminin ve değerinin; sağlık personellerinin hassasiyetinin bilinip kabul edilmesi gerekliliği yer almaktadır. Her bir sağlık personelinin psikolojik ve sosyal bir yapıya sahip olduğu kabul edilerek onların duygularına; duygularının davranışa dönüşme sürecine mümkün olduğunca önem vermelidirler. İmkanlar dahilinde birimlerde gözlem yapmaları da bir diğer öneridir. Bu sayede çeşitli olaylara ve durumlara karşı sağlı personel(ler)inin tepkileri doğrudan gözlemlenebilecektir. Tükenmişlik yaşamaya sebep olan unsurlara çok dikkat edilerek ortaya çıktığı daha ilk anda önlemler alınmalıdır. Sağlık personelinin örgütüne karşı özdeşim kurabilmesi için yönetimin anlayış ve desteği açıkça ortaya konulmalıdır.

Gelecekteki araştırmacılara yönelik öneriler ise; araştırmanın sınırlılıklarında da belertildiği üzere, çalışma nicel bir çalışma olmaktan öteye götürülerek nitel bir çalışmayla da desteklenerek karma bir çalışmaya dönüştürülebilir. Örneklem için İstanbul dışındaki şehirlere ve hatta bölgelere de yönelinebilir. Yalnızca özel yataklı hastanelerdeki sağlık personelleri üzerinde bir çalışma yapılmasının yanı sıra kamu hastaneler birliğine bağlı hastanelerdeki sağlık personelleri üzerinde de yapılarak mukayese imkânı elde edilebilir. Bunların yanı sıra, sağlık personellerinin kişilik özellikleri de ölçülerek model yeniden kurgulanabilir. 


\section{KAYNAKLAR}

Akça, F. (2008). Örgütsel Tükenmişlik ve Stres. M. Özdevecioğlu ve H. Karadal (Ed.), Örgütsel Davranışta Seçme Konular: Organizasyonların Karanlık Yönleri ve Verimlilik Azaltıcı Davranışlar, Ankara: İlke Yayınevi.

Altın-Gülova, A., Palamutçuoğlu, B. T. ve Terzi-Palamutçuoğlu, A. (2013). Duygusal emek ile işe bağlllık arasındaki ilişkide amir desteğinin rolü: Üniversitede öğrenci işleri personeline yönelik bir araştırma. Dokuz Eylül Üniversitesi İktisadi ve İdari Bilimler Fakültesi Dergisi, 28(2), 41-74.

Altunışık, R. (2012). Sosyal Bilimlerde Araştırma Yöntemleri SPSS Uygulamalı, Sakarya, Sakarya Üniversitesi İşletme Fakültesi, Sakarya Yayıncılık, 7. Baskı, 126.

Ashforth, B. E., Harrison, S. H. ve Corely, K. G. (2008). Identification in organizations: An examination of four fundametal questions. Journal of Management, 34, 325-374.

Ashforth, E. B. ve Humphrey, R. H. (1993) Emotional labor in service roles: The influence of identity. Academy of Management Review, 18 (1), 88-115.

Avşaroğlu, S., Deniz, M. E. ve Kahraman, A. (2005). Teknik öğretmenlerde yaşam doyumu, iş doyumu ve mesleki tükenmişlik düzeylerinin incelenmesi. Selçuk Üniversitesi Sosyal Bilimler Enstitüsü Dergisi, 14, 115-129.

Aypar, S. (2018). Örgütsel özdeşleşme, tükenmişlik, iş tatmini ve işten ayrılma niyeti ilişkisi: kamu kurumunda bir araştırma. Yüksek Lisans Tezi. Gazi Üniversitesi Sosyal Bilimler Enstitüsü, İşletme Anabilim Dalı Yönetim Organizasyon Bilim Dalı, Ankara.

Bartlett, J. E., Körtlik, J. W. ve Higgins, C. C. (2001). Organizational research: Determining appropriate sample size in survey research. Information Technology, Learning and Performance Journal, 19(1), 43-50.

Basım, H. N. ve Begenirbaş, M. (2012). Çalışma yaşamında duygusal emek: Bir ölçek uyarlama çalışması. Yönetim ve Ekonomi, 19(1), 77-90.

Basım, H. N. ve Şeşen, B. (2006). Mesleki tükenmişlikte bazı demografik değişkenlerin etkisi: Kamuda bir uygulama. Ege Akademik Bakış Dergisi, 6(2), 15-23.

Basım, H. N., Begenirbaş, M. ve Can-Yalçın, R. (2011), Öğretmenlerde kişilik özelliklerinin duygusal tükenmeye etkisi: Duygusal emeğin aracilık rolü. Kuram ve Uygulamada Eğitim Bilimleri Educational Sciences: Theory \& Practice, 13(3), 1477-1496.

Baumgartner, H., ve Homburg, C. (1996). Applications of structural equation modeling in marketing and consumer research: A review. International Journal of Research in Marketing, 13(2), 139-161.

Bayram, N. (2016). Yapısal Eşitlik Modellemesine Giriş: AMOS Uygulamaları. Bursa: Ezgi Kitabevi.

Bentler, P. M. (1980). Multivariate analysis with latent variables: Causal modeling. Annual Review of Psychology. $31,419-456$.

Bentler, P. M. ve Bonett, D.G. (1980). Significance tests and goodness of fit in the analysis of covariance structures. Psychological Bulletin, 88, 588-606.

Bitmiş, M. G., Sökmen, A. ve Turgut, H. (2013). Psikolojik dayanıklılığın tükenmişlik üzerine etkisi: Örgütsel özdeşleşmenin aracılık rolü. Gazi Üniversitesi İktisadi ve İdari Bilimler Fakültesi Dergisi, 15(2), 27-40.

Boymul, E. (2015). İş tatmini ve örgütsel bağlllı̆̆ın tükenmişlik üzerindeki etkisi: Bir sanayii kuruluşunda alan araştırması. Yüksek Lisans Tezi, Çağ Üniversitesi Sosyal Bilimler Enstitüsü İşletme Yönetimi Anabilim Dalı, Mersin.

Brotheridge C. M. ve Lee R. T. (2003) Development and validation of the emotional labor scale. Journal of Occupational and Organisational Psychology, 76, 365-379.

Brotheridge, C. M. ve Grandey, A. A. (2002). Emotional labor and burnout: Comparing two perspectives of "people work". Journal of Vocational Behavior, 60(1), 17-39. 
Browne, M. W. ve Cudeck, R. (1993). Alternative ways of assessing model fit. In: Bollen, K.A., \& Long, J.S. (Eds.), Testing structural equation models (136-162). Beverly Hills, CA: Sage.

Budak, G. ve Sürgevil, O. (2005). Tükenmişlik ve tükenmişliği etkileyen örgütsel faktörlerin analizine ilişkin akademik personel üzerinde bir uygulama. Dokuz Eylül Üniversitesi İ.̇.B.F. Dergisi, 20(2), 95-108.

Büyüköztürk, Ş., Çakmak, E. K., Akgün, Ö. E., Karadeniz, Ş. V. ve Demirel, F. (2012). Bilimsel Araştırma Yöntemleri. Pegem Yayıncılık, Ankara.

Byrne, B.M. (2001). Structural equation modeling with AMOS, EQS, and LISREL: Comparative approaches to testing for the factorial validity of a measuring instrument. International Journal of Testing, 1(1), 55-86.

Chau, S. L., Dahling, J. J., Levy, P. E. ve Diefendorff, J. M. (2009). A predictive study of emotional labor and turnover. Journal of Organizational Behavior, 30(8), 1151-1163.

Cheney, G. (1983). On the various and changing meanings of organizational membership: A field study of organizational identification. Communication Monographs, 50(4), 342-362.

Chu, K. H. L. ve Murrmann, S. K. (2006). Development and validation of the hospitality emotional labor scale. Tourism Management, 27, 1181-1191.

Cilasun, A. (2016). Yükseköğretim kurumlarında pozitif psikoloji ve örgütsel özdeşleşmenin performans yönetimine etkisi. Doktora Tezi. Çanakkale Onsekiz Mart Üniversitesi Eğitim Bilimleri Enstitüsü Eğitim Bilimleri Anabilim Dalı Eğitim Yönetimi ve Denetimi Bilim Dalı, Çanakkale.

Çelik, M. ve Turunç Ö. (2011). Duygusal emek ve psikolojik sıkıntı: İş-aile çatışmasının aracılık etkisi. İstanbul Üniversitesi İşletme Fakültesi Dergisi, 40(2), 226-250.

Çoruk, A. (2014). Yükseköğretim kurumlarında görev yapan idari personelin duygusal emek davranışları. Ondokuz Mayıs Üniversitesi Eğitim Fakültesi Dergisi, 33(1), 79-93.

Değirmenci, S. (2010). Hemşirelerin Duygusal Emek Davranışı ve Etkileyen Faktörler, İstanbul Üniversitesi, Yüksek Lisans Tezi, İstanbul.

Diefendorff, J. M., Gosserand, R. H. ve Croyle, M. H. (2005). The dimensionality and antecedents of emotional labor strategies. Journal of Vocational Behavior, 66, 339-357.

Dursun, I. (2019). Burnout on Employees Organizational Commitment: Five Star Hotel Employees, Journal of Business Research-Turk, 11 (1), 459-467.

Eray-Çelik, H., ve Yılmaz, V. (2016). Lisrel 9.1. İle Yapısal Eşitlik Modellemesi, Temel Kavramlar-UygulamalarProgramlama. Yenilenmiş 3. Baskı, Ankara: Anı Yayıncılık.

Ergin, C. (1992). Doktor ve hemşirelerde tükenmişlik ve Maslach tükenmişlik ölçeğinin uyarlanması. 7. Ulusal Psikoloji Kongresi Bilimsel Çalışmaları, Hacettepe Üniversitesi, Ankara, Turkey.

Gossett, L. (2002). Kept at arm's length: Questioning the organizational desirability of member identification. Communication Monographs, 69(4), 385-404.

Grandey, A. A. (1999). The Effects of Emotional Labor: Employee Attitudes, Stress and Performance. Doktora Tezi, Colorado: Colorado State University, Fort Collins.

Grandey, A. A. (2000). Emotion regulation in the workplace: A new way to conceptualize emotional labor. Journal of Occupational Health Psychology, 5(1), 95-110.

Grandey, A. A. (2003). When 'The show must go on': Surface acting and deep acting as determinants of emotional exhaustion and peerrated service delivery. Academy of Management Journal, 46(1), 86-96.

Hall, D. T., Schneider, B. ve Nygren, H. T. (1970). Personel factor in organizational identification. Administrative Science Quarterly, 176-191.

Hochschild A. (1983). The Managed Heart: Commercialization of Human Feeling. University of California Press, Berkeley.

İşcan, Ö. F. (2006). Dönüştürücü etkileşimci liderlik algısı ve örgütsel özdeşleşme ilişkisinde bireysel 


\section{S. Aksoy Kürü 13/1 (2021) 150-175}

farklılıkların rolü. Akdeniz Üniversitesi İktisadi ve İdari Bilimler Fakültesi Dergisi, 11, 160-177.

Jones, J.R. (1998). An Examination of the Emotional Labor Construct and its Effects on Employee Outcomes, University of Nebraska, Doktora Tezi, Lincoln.

Katrinli, A., Atabay, G., Günay, G. ve Güneri B. (2008). Leader-member exchange, organizational identification and the mediating role of job involvement for nurses. Journal of Advanced Nursing, 64(4), 354-362.

Kaya, İ. (2017). Okul yöneticileri ile öğretmenlerin örgütsel bağlllık ve tükenmişlik düzeyleri arasındaki ilişkisi. Yüksek Lisans Tezi. Marmara Üniversitesi İstanbul Sabahattin Zaim Üniversitesi, Eğitim Yönetimi ve Denetimi Ortak Lisansüstü Programları, İstanbul.

Kline, R. B. (2011). Principles and Practice Of Structural Equation Modeling. New York: The Guilford Press.

Köse, Ö. (2019). Presenteeism (İşte var olamama) ile örgütsel özdeşleşme ve tükenmişlik arasındaki ilişkinin analizi. Yüksek Lisans Tezi. İstanbul Sabahattin Zaim Üniversitesi Sosyal Bilimler Enstitüsü İşletme Anabilim Dalı İşletme Yönetimi Bilim Dalı, İstanbul.

Köse, S. ve Gülova, A. A. (2006). Tükenmişlik (Burnout): Türkiye'deki genel cerrahlara yönelik bir araştırma. 14. Ulusal Yönetim ve Organizasyon Kongresi, 25-27 Mayıs, Erzurum.

Kreiner, G. E. ve Ashforth, B. E. (2004). Evidence toward an expanded model of organizational identification. Journal of Organizational Behaviour, 25, 1-27.

Kruml, S. M. ve Geddes, D. (2000). Exploring the dimensions of emotional labor: the heart of Hochschild's work. Management Communication Quarterly, 14(8), 8-49.

Kruml, S. M. ve Geddes, D. (2000). Catching Fire without burning out: Is There an Ideal Way to Perform Emotion Labor? İçinde N. M. Ashkanasy, C. E. Härtel ve W. J. Zerbe (Ed.), Emotions in the Workplace (177-188). Westport, CT: Greenwood.

Lammers, J. C., Atouba, Y. L. ve Carlson, E. J. (2013). Which identities matter? A mixed-method study of group organizational, and professional identities and their relationship to burnout. Management Communication Quarterly, 27(4), 503-536.

Leidner, R. (1999). Emotional labor in service work. Annuals of the American Academy of Political and Social Science, 561, 81-95.

Mael, F. ve Ashforth, B. E. (1992). Alumni and their alma mater: A partial test of the reformulated model of organizational identification. Journal of Organizational Behavior, 13, 103-123.

Mael, F. ve Ashforth, B. E. (1995). Loyal from day one: Biodata, organizational identification, and turnover among newcomers. Personnel Psychology, 48(2), 309-333.

Marsh, H.W., Hau, K.T., Artelt, C., Baumert, J. \& Peschar, J.L. (2006). OECD's brief self-report measure of educational psychology's most useful affective constructs: Cross-cultural, psychometric comparisons across 25 countries. International Journal of Testing, 6(4), 311-360.

Maslach, C. ve Jackson, S. E. (1981) The measurement of experienced burnout, Journal of Occupational Behaviour, 2, 99-113.

Maslach, C. ve Zimbardo, P. G. (1982). Burnout: The Cost of Caring. Prentice Hall: New Jersey.

Maslach, C. ve Goldberg, J. (1998). Prevention of burnout: New perspectives. Applied \& Preventive Psychology, $7,63-74$.

Maslach, C., Schaufeli, W. B. ve Leiter, M. P. (2001). Job burnout. Annual Review of Psychology, 52, 397-422.

Meydan, C. H. ve Şeşen, H. (2015). Yapısal Eşitlik Modellemesi, Amos Uygulamaları. Ankara, Detay Yayıncllık.

Miller, V. D., Allen, M. Casey, M. K. ve Johnson, J. R.șe: (2000). Reconsidering the organizational identification questionnaire. Management Communication Quarterly, 13(4), 626-658. 
Moon, S. J. ve Han, S. S. (2011). A predictive model on turnover intention of nurses in Korean. Journal of Korean Academy of Nursing. 41(5), 633-641.

Morris, J. A. ve Feldman C. D. (1996). The dimensions, Antecedents and consequences of emotional labor. Academy of Management Review, 21 (4), 986-1010.

Morris, J.A. ve Feldman, D.C. (1997). Managing emotions in the workplace. Journal of Managerial Issues, 9(3), 257-274.

Nathan H. C. ve Herda, D. N. (2016). Auditors' organizational commitment, burnout, and turnover intention: a replication. Behavioral Research in Accounting, 28(2), 69-74.

Nunally, J. C. (1978). Psychometric Theory, McGraw-Hill, New York.

Öz, E., Ü. (2007). Duygusal emek davranışlarının çalışanların iş sonuçlarına etkisi. Doktora Tezi. İstanbul: Marmara Üniversitesi Sosyal Bilimler Enstitüsü, İstanbul.

Özgen, I. (2010). Turizm İşletmelerinde Duygusal Emek. Ankara: Detay Yayıncılık.

Polat, M. (2009). Örgütsel özdeşleşmenin öncülleri ve ardılları üzerine bir saha çalışması. Uludağ Üniversitesi Sosyal Bilimler Enstitüsü İşletme Anabilim Dalı Yönetim ve Organizasyon Bilim Dalı, Bursa.

Polatçı, S. (2007). Tükenmişlik sendromu ve tükenmişlik sendromuna etki eden faktörler (Gaziosmanpaşa Üniversitesi akademik personeli üzerine bir analiz). Yüksek Lisans Tezi, Gaziosmanpaşa Üniversitesi Sosyal Bilimler Enstitüsü İşletme Anabilim Dalı.

Riketta, M. (2005). Organizational identification: A meta-analysis, Journal of Vocational Behavior, 66, 358- 384.

Rode, J. C., Judge, T. A. ve Sun, J. M. (2012). Incremental validity of core self-evaluations in the presence of other self-concept traits: an investigation of applied psychology criteria in the United States and China. Journal of Leadership \& Organizational Studies, 19(3), 326-340.

Seçer, Ş. ve Tınar, M. Y. (2004). İş yerinde tükenmişlik kaynağı olarak duygusal emek: Hemşireler üzerinde yapılan bir araştırma", 9. Ulusal Ergonomi Kongresi, 16-18 Ekim 2003: 814-830.

Seery, B. L. ve Corrigall, E. A. (2009). Emotional labor: Links to work attitudes and emotional exhaustion. Journal of Managerial Psychology, 24(8), 797-813.

Soykan, E. (2012). Örgütsel bağlılık ve tükenmişlik ilişkisi: Eğitim sektöründe bir uygulama. Yüksek Lisans Tezi. Dicle Üniversitesi Sosyal Bilimler Enstitüsü, İşletme Anabilim Dalı, Diyarbakır.

Sürgevil, O. (2006). Çalışma Hayatında Tükenmişlik Sendromu: Tükenmişlikle Mücadele Teknikleri. Ankara: Nobel Yayın Dağıtım.

Şahin, E. (2014). Ortaöğretim kurumlarında örgütsel kimlik, örgütsel imaj, örgütsel özdeşleşme ve örgütsel adalet (Bursa Örneği). Ege Üniversitesi Sosyal Bilimler Enstitüsü Eğitim Bilimleri Anabilim Dalı Eğitim Yönetimi, Teftişi, Ekonomisi ve Planlaması Bilim Dalı, İzmir.

Tak, B. ve Aydemir, B. A. (2004). Örgütsel özdeşleşme üzerine iki görgül çalışma, 12. Ulusal Yönetim ve Organizasyon Kongresi, Uludağ Üniversitesi, Bursa.

Tompkins, P. K. ve Cheney G. (1985). Communication and Unobtrusive Control in Contemporary Organizations Organizational Communication: Traditional Themes and New Directions içinde. Der: McPhee, R.D.ve. Tompkins, P. K. Beverly Hills, CA: Sage, 179-210.

Tosun, N. ve Ulusoy, H. (2017). The relationship of organizational commitment, job satisfaction and burnout on physicians and nurses? Journal of Economics \& Management, 28, 90-111.

Uray, M. (2014). Müşteri odaklılık ve örgütsel güven ilişkisinde örgütsel özdeşleşme ve örgütsel bağlllı̆̆ın aracilık rolü ve bir araştırma. Doktora Tezi. Marmara Üniversitesi Sosyal Bilimler Enstitüsü İşletme Anabilim Dalı Yönetim ve Organizasyon Bilim Dalı, İstanbul.

Üngüren, E., Doğan H., Özmen M. ve Akgün, T. Ö. (2010). Otel çalışanlarının tükenmişlik ve iş tatmin düzeyleri ilişkisi. Journal of Yasar University, 17(5), 2922-2937. 
Van Knippenberg, D. ve Van Schie, E. C. M. (2000). Foci and correlates of organizational identification. Journal of Occupational and Organizational Psychology, 73, 137-147.

Van, Dick. R., Wagner U., Stellmacher, J. ve Christ, O. (2004). The utility of a broader conceptualization of organizational identification: Which aspects really matter? Journal of Occupational and Organizational Psychology, 77, 171-191.

Wharton, A. (1993). The affective consequences of service work. Work and Occupations, 20(2), 205-232.

Yazıcıŏ̆lu, Y. ve Erdoğan, S. (2014). SPSS uygulamalı bilimsel araştırma yöntemleri. Ankara: Detay Yayıncılık.

Yeşiltaş, M., Çeken, H. ve Sormaz, Ü. (2012). Etik liderlik ve örgütsel adaletin örgütsel sapma davranışları üzerindeki etkisi. Muğla Üniversitesi Sosyal Bilimler Enstitüsü Dergisi (28), 19-39.

Yıldırım, M. H. ve İçerli, L. (2010). Tükenmişlik sendromu: Maslach ve Kopenhag tükenmişlik ölçeklerinin karşılaştırmalı analizi. Organizasyon ve Yönetim Bilimleri Dergisi 1, 123-131.

Yıldız, S. M. (2015). Lider-Üye Etkileşimi, İşyerinde Mobbing ve Mesleki Tükenmişlik İlişkisi, Ankara, Detay Yayıncilik.

Yılmaz, C. (2014). Örgütsel güven ile tükenmişlik arasındaki ilişkide algılanan örgütsel özdeşleşmenin aracıllk etkisi: Uygulamalı bir çalışma. Yüksek Lisans Tezi. Nevşehir Hacı Bektaş Veli Üniversitesi Sosyal Bilimler Enstitüsü, İşletme Anabilim Dalı, Nevşehir.

Yürür, S. ve Ünlü, O. (2011). Duygusal emek, duygusal tükenme ve işten ayrılma niyeti ilişkisi. İş, Güç Endüstri İlişkileri İnsan Kaynakları Dergisi, 13(2), 81-10.

Zengin, E. ve Erdal, A. (2000). Hizmet sektöründe toplam kalite yönetimi. Journal of Qafqaz University, 3(1), 4356.

Zhou, J., Yang, Y., Qiu, X., Yang, X., Pan, H., Ban, B. Qiao, Z., Wang, L. ve Wang, W. (2018). Serial multiple mediation of organizational commitment and job burnout in the relationship between psychological capital and anxiety in Chinese female nurses: A cross-sectional questionnaire survey. International Journal of Nursing Studies, 83, 75-82. 